\title{
Evolution of the Kurile-Kamchatkan Volcanic Arcs and Dynamics of the Kamchatka-Aleutian Junction
}

\author{
G. P. Avdeiko, D. P. Savelyev, A.A. Palueva, and S. V. Popruzhenko \\ Institute of Volcanology and Seismology, East Division of Russian Academy of Science, \\ Petropavlovsk-Kamchatsky, Russia
}

The Cenozoic tectonic evolution of the Kurile-Kamchatkan arc system has been reconstructed based on the spatial-tectonic setting of the volcanic-rock formations and their petrologic-geochemical characteristics, using gravity and seismic data. Three volcanic arc trench systems of different ages that become successively younger toward the Pacific have been recognized in the region: the West Kamchatka (Eocene), Mid-Kamchatka-Kurile (Late Oligocene-Quaternary), and Recent Kurile-Kamchatka systems. The Kamchatka volcanic belts are viewed as the products of these systems, which originated above the subduction zones. The geometry of the present-day Kurile-Kamchatka subduction zone and dynamics of contemporary volcanism can be defined from seismic data. The contemporary Kurile-Kamchatka arc can be subdivided into individual segments in accord with its tectonic evolution and geodynamics. The East Kamchatka segment represents the initial subduction stage (7-10 Ma ago) of the Pacific Plate. The Petropavlovsk segment (the MalkaPetropavlovsk zone of transverse faults) is a zone of discordant superposition of the contemporary Kurile-Kamchatka arc over the older Mid-Kamchatka arc. Within the South Kamchatka segment subduction remained practically unchanged since the Late Oligocene, i.e., since the origin of the Mid-Kamchatka-Kurile arc system, as well as within the three Kurile segments. Geodynamics controlled magma generation and is imprinted in the petrochemical properties of the volcanic rocks. Typical arc magmas are generated at the steady-state geodynamic regime of subduction. Lavas of an intraplate geochemical type are generated at initial and final stages of subduction, and also at the Kamchatka-Aleutian junction.

\section{INTRODUCTION}

The Kurile-Kamchatkan subduction system is a very appropriate region for the reconstruction of volcanic arc (VA) evolution and of the geodynamic conditions of VA volcanism and magma generation for a number of reasons. First, the Kurile segment of this system is a typical island arc

Volcanism and Subduction: The Kamchatka Region Geophysical Monograph Series 172

Copyright 2007 by the American Geophysical Union. 10.1029/172GM04 with a steady-state regime of subduction, but Kamchatka is an active continental margin with three VA of different ages. Second, within Kamchatka there are VA temporally positioned at the initial stage of subduction (Eastern Kamchatka) and at the final stage of subduction (the Sredinny Range). Third, typical VA rocks are distributed on the Kuriles and in South Kamchatka, whereas some volcanic rocks with intraplate geochemical characteristics coexist with predominant VA rocks in East Kamchatka and in the Sredinny Range [Volynets, 1994]. And finally, a transition from arc to oceanic volcanic rocks takes place at the Kamchatka-Aleutian 
junction [Portnyagin et al., 2005]. Additionally, high magnesian basalts and adakites occur in this region [Volynets et al., 1999; Yogodzinsky et al., 2002].

This paper is an attempt to synthesize modern spatialstructural, petrological and geochemical data in relation to the tectonic evolution and volcanism of the KurileKamchatkan VA system, with the aim of reconstruction of geodynamic conditions of different types of VA volcanism and establishing criteria for paleotectonic reconstructions of volcanism of ancient subduction zones.

\section{GEOLOGICAL AND GEOPHYSICAL DATA}

\subsection{Geology Framework of Kamchatka}

The Kamchatka peninsula has been developing as an oceancontinent transition zone for a long time. Allochthonous and autochthonous geological formations comprise its structure (Plate 1). Autochthonous terrigenous and volcanogenic complexes were formed during island arc stages of development beginning from the Paleogene. Allochthonous complexes were formed in different geological and geodynamic conditions and were accreted to Kamchatka in the Late MesozoicEarly Cenozoic time. Now the majority of them, excluding geological complexes of the eastern peninsulas, form a basement for the Kamchatka volcanic arcs (Plate 1). The most ancient rocks of the basement obviously are metamorphic complexes of the Sredinny and Ganalsky Ranges, but their age has been a subject of debate for almost a half century. At first geologists assumed that the metamorphic rocks were Precambrian. Later, it was determined that allochthonousfolded structure of Sredinny and Ganalsky massifs and metamorphism of separate allochthonous units were related to collision processes in Mesozoic and Cenozoic time [Rikhter, 1991, 1995; Konstantinovskaya, 2001].

Sredinny metamorphic massif (Plate 1) is composed of several main units that differ in structure and degree of metamorphism. The lower unit (Kamchatskaya Unit) contains a high-grade metamorphic core composed of granulite facies rocks [Rikhter, 1995]. Amphibolite-facies rocks (Malkinskaya Unit) are thrust over the rocks of Kamchatskaya Unit in periclinal zones, and along the eastern margin of the metamorphic core. Terrigenous, volcanic-siliceous and volcaniclastic rocks were protoliths for the rocks of Kamchatskaya and Malkinskaya Units. Originally these rocks were formed as a result of transportation of terrigenous material to a backarc basin and volcanic arc. During collision, the continental margin and arc rocks were metamorphosed and intruded by plagiogranites, $\mathrm{Rb} / \mathrm{Sr}$ dated as $127 \mathrm{Ma}$ [Vinogradov et al., 1991]. Along the eastern margin, the Sredinny metamorphic massif is tectonically covered by Upper Cretaceous terrig- enous and volcanic-siliceous deposits of Khosgonskaya and Iruneyskaya Units.

The Ganalsky metamorphic massif (Plate 1) consists of three allochthonous units. The uppermost contains phyllite and chlorite-biotite facies rocks, the middle one includes greenshists and epidote amphibolites, and the lower unit is made of garnet amphibolites [Rikhter, 1991]. In contrast to the Sredinny massif, the protoliths for these metamorphic rocks were oceanic basalts, pelagic siliceous rocks, limestones and also VA rocks. Tectonic slices are often separated by metamorphized ultramafics and serpentinite melange. The metamorphism is related to arc-continent collision. ${ }^{39} \mathrm{Ar} /{ }^{40} \mathrm{Ar}$ age from garnet amphibolites (50.6-47 Ma) indicate that the amphibole-grade metamorphism occurred before the end of Early Eocene [Konstantinovskaya, 2001].

Metamorphic rocks also occur in the structure Khavyvenskaya Rise (Plate 1) and comprise blocks in serpentinite melanges on the Ozernoy Peninsula, Kamchatsky Mys Peninsula and northern part of Kumroch Range. These units consist of amphibolites, green slates, and rare quartzites. The metamorphism is related with subduction of an oceanic plate, fragments of which were thrust to the surface in the process of the tectonic reorganization [Osipenko et al., 2005].

Besides metamorphic rocks, the basement of Cenozoic volcanic arcs includes Late Cretaceous - Paleocene units, the composition of which varies for different tectonic zones (Plate 1). The basement of West Kamchatka and of the MidKamchatka arcs (Sredinny Range) is Upper Cretaceous terrigenous deposits (Khosgonskaya and Lesnovskaya Units), volcanic-siliceous rocks of Iruneyskaya Unit, and volcanic formations of VA-type of the Upper-Cretaceous-Paleocene Kirganikskaya Unit. Terrigenous deposits were formed by transportation of material from a continental margin to a back-arc basin, often as turbidites. Volcanic-siliceous deposits of the Iruneyskaya Unit were clearly formed in back-arc spreading conditions.

Within Eastern Kamchatka (in the Valaginsky and Kumroch Ranges, on the Ozernoy Peninsula), the basement is represent by Upper Cretaceous volcanic, volcano-terrigenous and siliceous rocks (Khapitskaya and Kitilginskaya Units), which were formed in the conditions of an ensimatic island arc. Paleocene-Lower Eocene complexes consist of continental-derived turbidites. Deposits of different arc facies were tectonically combined and formed the accretion structure of basement of the modern volcanic arc of Eastern Kamchatka. The east part of Kumroch Ridge and southern part of Valaginsky Ridge are characterized by series of tectonic slices, which comprise the accretionary complex of Paleocene-Early Eocene age (Vetlovka Unit). This unit contains volcaniclastic rocks, pelagic radiolarites, limestones, 


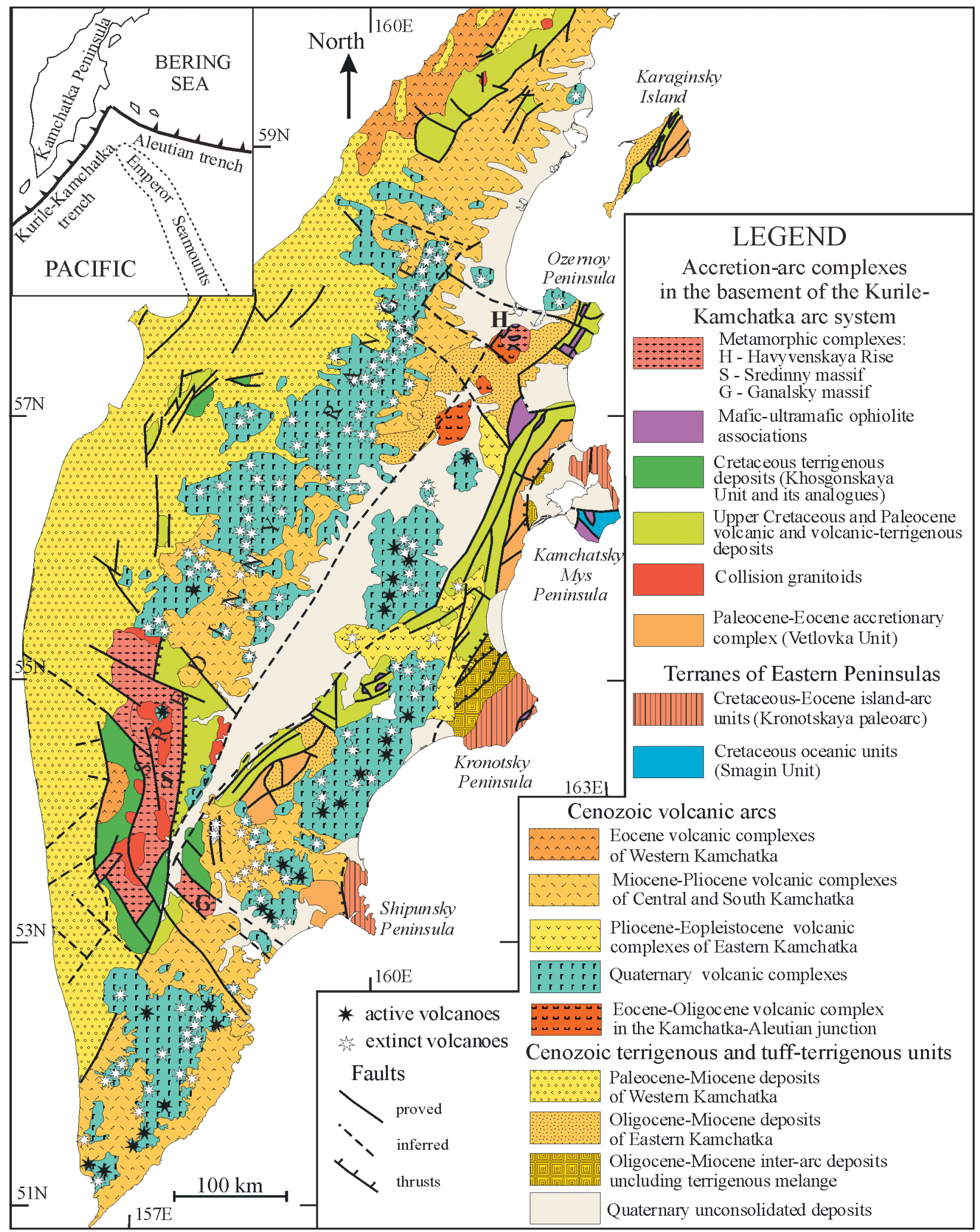

Plate 1. Generalized tectonic map and geologic formation complexes of Kamchatka. 
MORB-like basalts, and diabases formed in the Vetlovka oceanic basin [Konstantinovskaya, 2001].

Terranes of eastern peninsulas (Kamchatsky Mys, Kronotsky and Shipunsky) form a frontal (tectonic) arc in the modern structure of Kamchatka (Plate 1). They are parts of the Kronotskaya paleoarc formed in the central part of Pacific and accreted to the Kamchatka [Khubunaya, 1987; Levashova et al., 2000]. Upper Cretaceous-Eocene marine volcanogenic-sedimentary rocks are characteristic for this arc. The peninsulas are separated from the rest of Kamchatka by a long trough, the Tyushevskiy paleobasin, filled with Upper Eocene-Miocene terrigenous sediments. The western border of the Tyushevskiy trough is a large zone of easttrending thrust (Grechishkin Suture) formed as a result of accretion of the Kronotskaya paleoarc. There are two points of view on the time of collision of the Kronotskaya paleoarc with Kamchatka. According to one of them [Tsukanov, 1991], it took place in the Middle Eocene phase of compression simultaneously with the main structural reorganization of the entire region. According to other authors [Avdeiko et al., 1999; Konstantinovskaya, 2001], tectonic accretion of the Kronotskaya paleoarc took place in the Late Miocene (7-10 Ma ago), and resulted in closing of the Tyushevskoy basin and jump of the subduction zone to the present-day position.

Much interest is focused on the structure of Kamchatsky Mys Peninsula where there are ophiolites and volcanic rocks of the OIB and IAB types. This terrane occupies a key position at the Kamchatka-Aleutian junction. The geological structure of this area consists of intrusive, volcanic and sedimentary complexes from the Cretaceous to Quaternary that were formed in a variety of geodynamic conditions (Plate 1). Data on rock composition and age allow us to reconstruct the history of development of this area.

The southern part of the Kamchatsky Mys Peninsula is composed of components of an ophiolite assotiation - ultrabasic rocks, gabbro, dikes and lavas of the basalts, as well as Cretaceous silicic-volcanic and terrigenous sedimentary rocks. Some amphibolites occur as blocks in a serpentinite melange. Volcanoclastic tuff and chert deposits with pillowbasalt, jasper and limestone are melded with in the Smagin Unit. The age of this sequence was estimated to be AlbianCenomanian by the radiolarian assemblage from jasper in the limestones. This complex contains a suite of MORB-like tholeiites and high- $\mathrm{K}_{2} \mathrm{O}$ alkali basalts [Fedorchuk, 1992; Savelyev, 2003; Portnyagin et al., 2005b]. Alkali basalts constitute about $5-7 \%$ of the volcanic rocks in the Smagin Unit and their geochemical characteristics correspond to those of ocean island basalts (OIB). The high content of K, $\mathrm{P}, \mathrm{Nb}$ and LREE in these rocks is similar to alkali basalts of the Emperor Seamount Chain. Thus, composition and age connects the formation of Kamchatsky Mys alkali basalts to activity of the Hawaiian mantle plume [Avdeiko and Savelyev, 2005]. Deposits of the Smagin Unit are overlain by Turonian-Campanian sandstones and siltstones of the Pikezh Unit. The northern part of Kamchatsky Mys Peninsula is composed of Cretaceous - Middle Eocenian terrigenous-volcanogenic deposits of the Stolbovskaya Unit similar to those of Kronotsky and Shipunsky Peninsulas of the same age. Primitive tholeiites and high-Al basalts, typical for ensimatic island arcs, predominate in it [Khubunaya, 1987; Tsukanov, 1991]. During the Early Eocene, ophiolite complexes were eroded from this arc, as evidenced by abundant serpentinite fragments in sandstones of the Stolbovskaya Unit.

A model of geological development was constructed consistent with these data. Early Cretaceous: oceanic crust was formed in the axial zone of a mid-oceanic ridge (ultrabasic rocks, gabbro, basalts MORB-type). Albian-Cenomanian: an intra-oceanic rise was formed on the flanks of an anomalous segment of this mid-oceanic ridge, affected by the adjacent Hawaiian mantle plume (i.e., the Smagin Seamount composed of tuffaceous sediments, tuffs, limestones with jasper, MORB-like tholeiites, and high- $\mathrm{K}_{2} \mathrm{O}$ alkali basalts). Turonian-Campanian: the Smagin Seamount migrated into a continental margin into a zone of terrigenous sedimentation (sandstones and siltstones of Pikezh Unit). CampanianMaastrichtian: Kronotskaya arc began to form on oceanic crust. Active volcanism in this arc continued up to Eocene and volcanogenic-sedimentary deposits accumulated. Middle Eocene: a large tectonic reconstruction occurred as the Pacific plate changed its direction. Collision of AchaivayamValaginskaya arc with Kamchatka [Konstantinovskaya, 2000]: This is a stage of folding and metamorphism. Possibly at the same time, the Smagin Seamount collided with the Kronotskaya arc. Late Eocene: Volcanism stopped in the Kronotskaya arc. Oligocene and Early Miocene: the Kronotskaya arc continued its passive motion on the Pacific oceanic plate. The Tyushevskiy basin (with accumulated terrigenous deposits) was situated between Kamchatka and the inactive Kronotskaya arc . Kamchatka collided with the Kronotskaya inactive arc and Smagin Seamount in Late Miocene (7-10 Ma ago). This collision caused the latest tectonic reconstruction of East Kamchatka and a jump of the subduction zone to their present-day position. The Smagin Seamount was separated from the rest of the Emperor Seamount Chain.

\subsection{Distribution of VA Formations}

Three VA complexes of different age were formed within the Kurile-Kamchatka VA system (Fig. 1). The Eocene volcanic and subvolcanic rock complexes from basalts to 


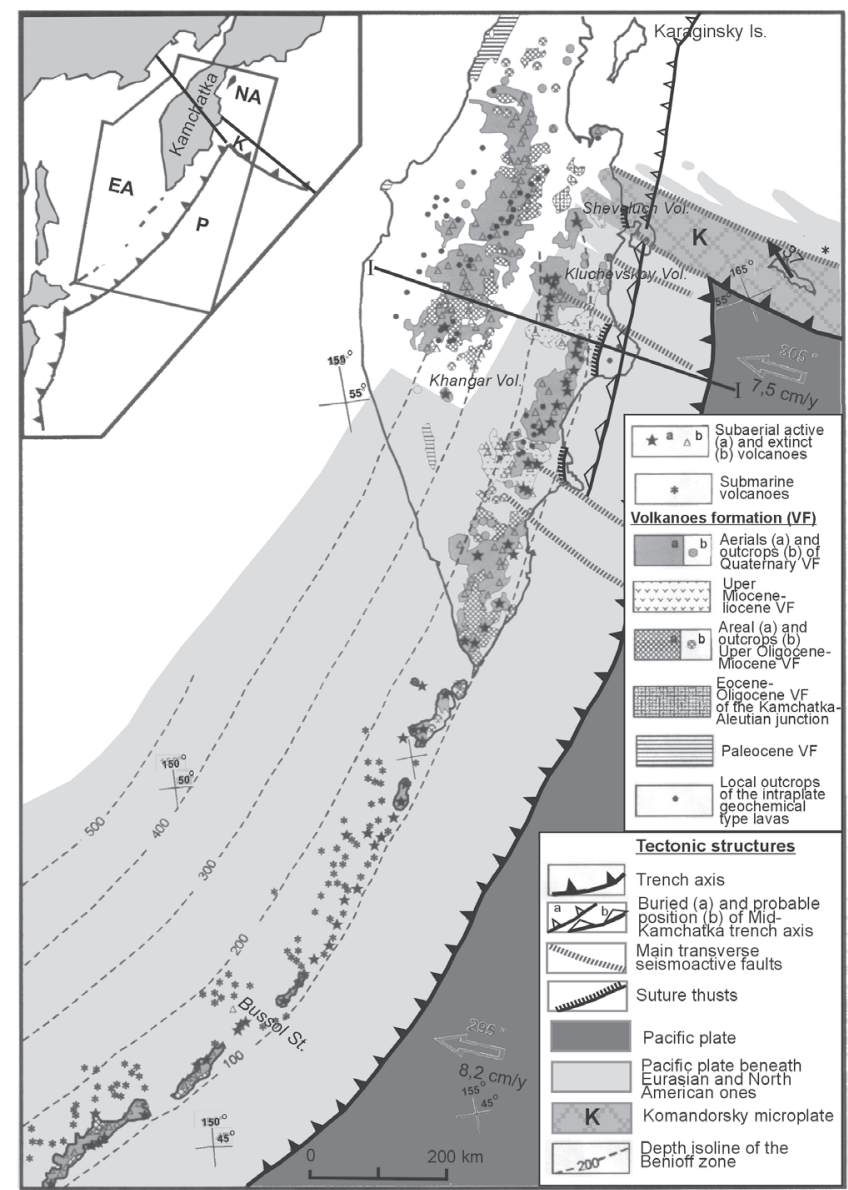

Figure 1. Spatial distribution of Cenozoic subduction-related volcanic formations in the Kurile-Kamchatka island-arc system. I-I location of model cross-section on Fig. 4. On the incut: EA - Eurasian, NA - North American, P - Pacific plates, K - Komandorskaya microplate.

rhyolites (Kinkil unit) stretch out along the western coast and depression of the Parapolsky Dol [Filatova, 1988; Bogdanov, Khain, 2000].

The associations of Neogene-Quaternary volcanic and intrusive rocks from basalts to dacites and liparites are widespread within the Sredinny ridge of Kamchatka and Southern Kamchatka. Rocks of both normal and alkalic series, i.e. trachybasalts, trachyandesites, etc., occur among them. Some data indicate that the oldest are of Late Oligocene age [Litvinov, Patoka, 1999], but other data indicate that they are Miocene [Sheimovich, Patoka, 2000]. Detailed geological and petrographic descriptions of these rocks are reported in a number of publications [Ogorodov et al., 1972; Volynets, 1994]. Sheimovitch and Patoka [2000] distinguish six volcanoplutonic formations in Southern Kamchatka and the Sredinny Range: Miocene andesite, Miocene-Pliocene liparite-dacite,
Pliocene basic andesites, Early Pleistocene basalt, PleistoceneHolocene basaltic andesites (to which all active volcanoes belong), and Holocene basalts (distributed, monogenic volcanism). It should be noted that the name of the formations is the predominant rock type. Two basic features distinguish VA formation complexes of the Sredinny Range from ones of Southern Kamchatka: (1) only typical VA volcanic formations are distributed on Southern Kamchatka, whereas some volcanic rocks of the intraplate non-VA geochemical type occur in the Sredinny Range among the predominant typical VA lavas [Volynets, 1994], (2) only two potentially active volcanoes, Ichinsky and Khangar, are in the Sredinny Range [Melekestsev et al., 2001], whereas active volcanism is wellspread within South Kamchatka.

VA volcanic rocks of the Great Kurile Islands have a similar composition. "Green tuff", volcanogenic-siliceous-diatomite, andesite-basaltic andesite, and andesite formation complexes have been described there [Sergeev, Krasny, 1987; Piscunov, 1987]. The oldest of these is the Oligocene-Middle Miocene green-tuff complex, whose volcanic rocks are represented by basalt, basaltic andesite, andesite, and dacite lavas along with volcanic breccias of the same compositions. Quartz diorite is the only representative of intrusive rocks. The Middle Miocene-Pliocene volcanogenic-siliceous-diatomite complex contains large amounts of andesite and dacite pumice and may be comparable to the rhyolite-dacite rock association of Southern Kamchatka. The andesite-basaltic andesite complex of the Kurile Islands is close both in age and composition to the basaltic andesite rock association of South Kamchatka. Pillow lavas, detrital-pillow breccias, and aquagene tuff are characteristic of this complex. All three pre-Quaternary volcanic-rock complexes occur only at the flanks of the Greater Kurile Islands: on the Shumshu and Paramushir islands (North Kuriles) and on the Urup, Iturup and Kunashir (South Kuriles). Volcanic rocks of the Kurile Islands display evident features of submarine eruption, in contrast to those of the South Kamchatka and Sredinny Range of Kamchatka. The andesite complex of the Kurile Islands is represented by basalt, basaltic andesites, andesites, and dacites of Quaternary volcanoes, many of which are active. The Quaternary submarine volcanoes located on the back-arc part of the Great Kurile Islands were studied in detail during 9 cruises of R/V "Vulkanolog". They also are represented by basalts, basaltic andesites and andesites [Avdeiko et al., 1991].

In East Kamchatka, including the Central Kamchatka Depression, Oligocene-Miocene volcanic rocks of the VA type are absent, in contrast to the Kamchatka Sredinny Range, Southern Kamchatka, and the Kurile Islands. Here, a large group of Pliocene and Pliocene-Early Pleistocene volcanic complexes composed of basalt, andesite, and dacite 
lavas in variable proportions and of subvolcanic facies of the same rocks have been recognized [Litvinov, Patoka, 1999]. There are also modern volcanoes (Fig. 1). In addition, there are some small volcanic bodies of alkaline and subalkaline basalts with intraplate geochemical characteristics [Volynets et al., 1990; Volynets, 1994]. These are Late Miocene rocks and are the oldest volcanic products within the Eastern Kamchatka VA belt.

On the whole, Pliocene-Quaternary VA rocks are most common within the Kurile-Kamchatka system. Their compositions range from basalts to dacites and rhyolites and vary across different regions. Basaltic andesites and andesites are predominant rocks on the Kurile Islands, while basalts and basic basaltic andesite are predominant in Kamchatka.

\subsection{Chemical Characteristics of VA Formations}

The chemical composition of lavas is most completely studied for the Pliocene-Quaternary association of volcanic rocks [Avdeiko et al., 1991; 1992; Volynets, 1994)] Within the Kuriles and Kamchatka lavas there can be distinguished low-K, moderate-K, high-K, and shoshonite-latite series and normal and subalkalic series. Following the criteria of Miyashiro [1974], tholeiitic and calc-alkaline differences are distinguished within every series. Calc-alkali, moderate-K series predominate in both Kamchatka and Kuriles and are usually found within frontal zones of the volcanic arcs: on the Kuriles and on east Kamchatka, where they are wide spread, on the Central Kamchatka Depression and on the Sredinny Range, where they appear only sporadically along the eastern margins of these structures [Volynets, 1994]. Lavas of high-K series are localized within the rear zones of the Kuriles, south and east Kamchatka and the Sredinny Range. Lavas of shoshonite-latite series occur in the rear zones of the northern Kuriles (and only among basalts), south Kamchatka and Central Kamchatka Depression, but are more common in the Sredinny Range where they are found in the central and rear zones of the volcanic belt.

The distribution of rocks of different series is interrupted by large transverse fault structures, where lavas of the high$\mathrm{K}$ series are found even in the frontal zones of volcanic belts, for example, at the bend of the Kurile arc in the area of Bussole strait [Avdeiko et al., 1992], and in the area of the Malko-Petropavlovsk zone of transverse dislocations in Kamchatka [Baluev et al., 1979].

Among the VA associations of the Kuriles, south and east Kamchatka, a transverse mineralogical and geochemical zonation is well manifested while a longitudinal zonation is less distinct [Avdeiko et al., 1991; Volynets, 1994]. Lavas of the frontal volcanic zones are characterized mainly by two-pyroxene phenocrysts, whereas in basalts of the rear zones phenocrysts of orthopyroxene are seldom seen. Phenocrysts of amphibole and biotite are wide spread in andesites and acid rocks and sometimes even in basalts of rear zones while they are absent in analogous rocks of the frontal zone. Similar minerals from different zones also vary in chemical composition [Volynets et al., 1990 b; Volynets, 1994; Osipenko, 2000].

Transverse geochemical zoning is expressed in increasing concentrations of many incompatible trace elements $(\mathrm{K}, \mathrm{Rb}$, $\mathrm{Li}, \mathrm{Be}, \mathrm{Ba}, \mathrm{Sr}, \mathrm{U}, \mathrm{Th}, \mathrm{La}, \mathrm{Ce}, \mathrm{Nb}, \mathrm{Ta}, \mathrm{Zr}, \mathrm{W}, \mathrm{Mo}$ ) in lavas from front to rear. $\mathrm{K} / \mathrm{Na}, \mathrm{Rb} / \mathrm{Sr}, \mathrm{La} / \mathrm{Yb}, \mathrm{Sr} / \mathrm{Ca}, \mathrm{Th} / \mathrm{U}$, and $\mathrm{Mg} /(\mathrm{Mg}+\mathrm{Fe})(\mathrm{Mg} \#)$ ratios, as well as contents of volatile components $\left(\mathrm{H}_{2} \mathrm{O}, \mathrm{F}, \mathrm{Cl}, \mathrm{S}\right)$, also increase in the same direction. In contrast, contents of $\mathrm{Fe}, \mathrm{V}$, and $\mathrm{Fe}^{2+} / \mathrm{Fe}^{3+}$ decrease in lavas in the same direction. A well pronounced isotope zonation has been defined in the Kurile lavas: ${ }^{87} \mathrm{Sr} /{ }^{86} \mathrm{Sr}$ and ${ }^{143} \mathrm{Nd} /{ }^{144} \mathrm{Nd}$ values decrease notably from the front to the rear [Volynets et al., 1988; Avdeiko et al., 1991].

Similar transverse zoning is manifested in the Quaternary VA-type volcanic products of the Sredinny Range, with higher general alkalinity and higher level of the incompatible trace elements concentrations [Volynets et al., 1987; 1990].

Two volcanic zones, front and rear, parallel to the deepsea trench with a zone of weak volcanic activity between them, are distinctly displayed in the Kuriles and in southern Kamchatka [Avdeiko et al., 1991; 1992]. The volcanic belt of the Central Kamchatka Depression can also be interpreted as a rear zone relative to the frontal one of Eastern Kamchatka (Fig. 1). In any event, the same regularities of geochemical zoning as in the Kuriles and south Kamchatka are characteristic of these zones [Volynets et al., 1990; Volynets, 1994].

In addition, lavas of an intraplate geochemical type were discovered and described by Volynets [1994] among the Late Cenozoic volcanic rocks of Kamchatka. In contrast to typical VA lavas, these are characterized by high concentrations of $\mathrm{Ta}, \mathrm{Nb}$, and $\mathrm{Ti}$, with a $\mathrm{Ta}-\mathrm{Nb}$ minimum in the rock/primitive mantle spider-diagram that is small or absent [Volynets, 1994; Avdeiko and Savelyev, 2005]. In addition, they are also characterized by modestly high concentrations of incompatible elements like volcanic rocks of the rear zones (Fig. 2). "Intraplate" lavas of Kamchatka include the following volcanic series: $\mathrm{K}-\mathrm{Na}$ alkaline basalts (of Late Miocene age in eastern Kamchatka); K-Na alkaline olivine basalts (Pliocene in eastern Kamchatka and Late Pliocene-Holocene in the Sredinny Range, where they comprise a zone of flood-basalt volcanism); K-Na basalt-comendite (of Pliocene-Early Pleistocene age in the Sredinny Range); and K-basalt and associated shoshonite-latite series (Late Miocene-Pliocene in between the Western Kamchatka and Sredinny Range). No systematic transverse geochemical zonation was found among lavas of the intraplate geochemical type. 


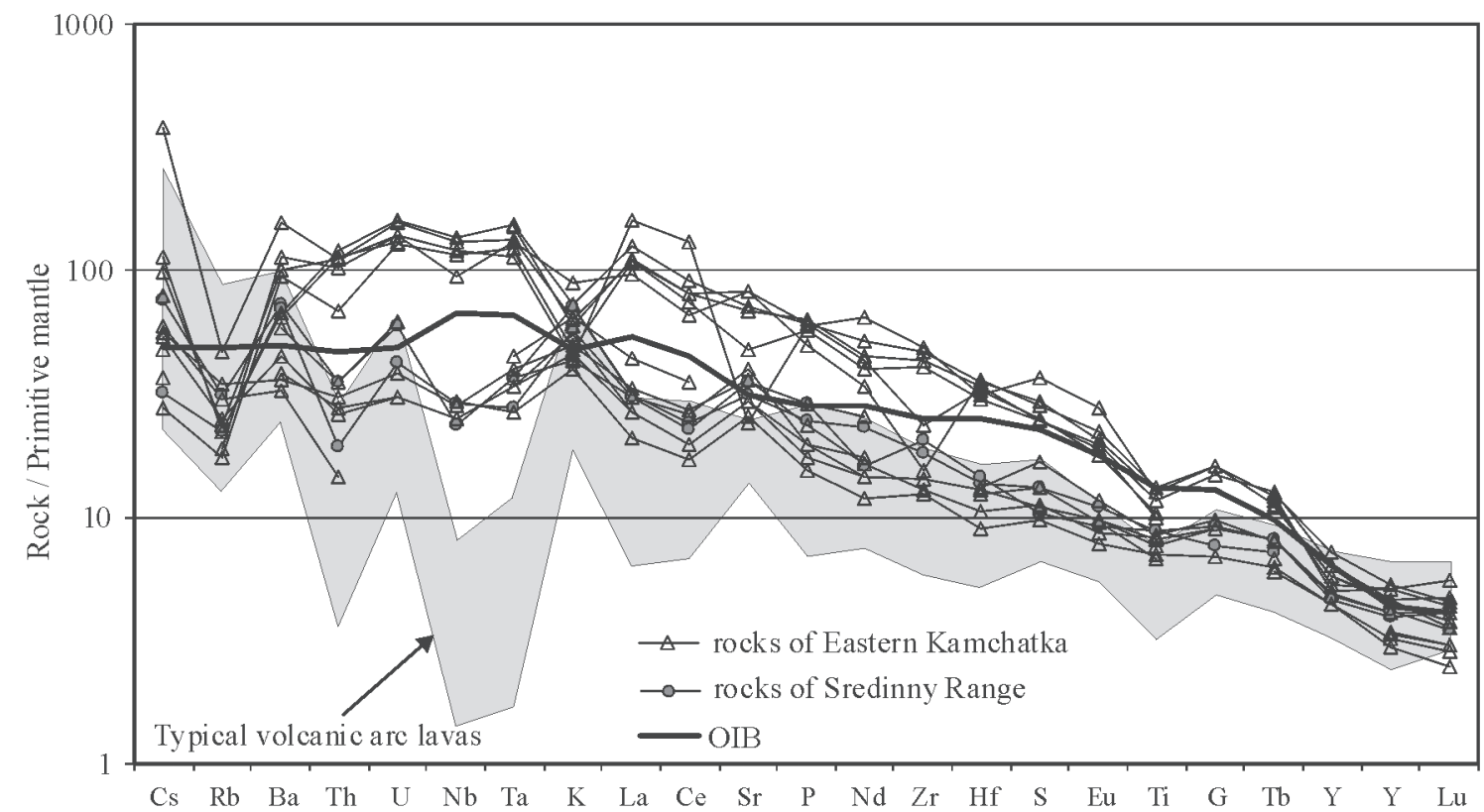

Figure 2. Primitive mantle-normalized trace element for intraplate-type volcanic rocks of Kamchatka. OIB and primitive mantle composition after Sun and McDonough (1989), typical arc lavas of Central Kamchatka Depression (35 samples) after Churikova et al. (2001)

There are some unusual characteristics of subductionrelated volcanic rocks in the Kamchatka-Aleutian junction area. One is the wide distribution here of high-magnesian basalts, basaltic andesites and andesites, including adakites [Volynets et al., 1998; 1999 a]. The volume of magnesian rocks of this area is approximately 10 times more than in all other areas of Kamchatka. Within the magnesian rocks there are certain regularities. Magnesian basalts (Mg\# 80-88) of the northern volcanoes (Shiveluch, Kharchinsky, Zarechny) have lower $\mathrm{Ca}$, higher $\mathrm{Sc}, \mathrm{Y}, \mathrm{Yb}$ concentrations and higher $\mathrm{K} / \mathrm{Ti}, \mathrm{La} / \mathrm{Yb}, \mathrm{Ni} / \mathrm{Sc}$, and $\mathrm{La} / \mathrm{Ta}$ ratios compared to the similar ones from the Kluchevskaya group of volcanoes. Most of the volcanic rocks of this region are characterized by high alkalinity and high LILE and LREE concentrations. Volcanoes of the Kluchevskaya group are characterized by a very high productivity, supplying about $1 / 3$ of volume of the volcanic material erupted by all Kamchatka volcanoes and two times more than east Kamchatka volcanoes during Holocene time [Volynets et al., 1998; Kozhemyaka, 2000]. These unusual features of volcanism reflect the unique geodynamic conditions of the Kamchatka-Aleutian junction.

The data on the distribution, age and chemical composition of VA rocks testify that the volcanic belt of the Sredinny Range is different from the Eastern Kamchatka belt. The origin of the Late Oligocene-Quaternary volcanic belt in the Sredinny Range is still a matter of debate. Some authors interpret it as an independent volcanic arc located above a separate subduction zone under the Sredinny Range. This belt has now completed its development as the result of a blockade of its subduction zone by accretion of the eastern peninsulas to Kamchatka [Legler, 1977; Avdeiko et al., 1999; Trubizin et al., 1998]. Other authors believe that the volcanic belt of the Sredinny Range is related to the present-day Kurile-Kamchatka subduction zone, being a third volcanic zone, a back-arc one relative to the Eastern volcanic zone and the volcanic zone of the Central Kamchatka depression [Tatsumi et al., 1994; Seliverstov, 1998]. The origin of the Sredinny Range volcanic belt will be discussed below.

\subsection{Gravity Data}

The gravity field of the present-day Kurile-Kamchatka arc-trench system has principal gravity features characteristic of such systems, i.e., the presence of conjugate positive and negative free-air gravity anomalies [Watts et al., 1975; 1978]. The positive anomaly extends along the tectonic (frontal) arc, which encompasses the Lesser Kurile Islands and their submarine extension in the Kuriles, as well as the eastern peninsulas in Kamchatka. The positive anomaly is complicated by transverse lower-intensity gravity anomalies along large transverse fault zones in the areas of the Gulf of Avacha in Kamchatka and of the Bussol Strait in the Kuriles [Watts et al., 1978]. 
The volcanic belts of East Kamchatka, the Central Kamchatka Depression, and the Sredinny Range show a mosaic of alternating Bouguer gravity fields (Plate 2) [Popruzenko et al., 1987]. The character of the anomalies in the areas of volcanic cones is controlled by the structure and composition of the basement rocks, the genetic type and maturity of volcanic centers, the state of isostatic equilibrium, and other factors. For example, local gravity maxima, complicated by gravity ring minima at their margins, mark basalt and some andesite volcanoes. Volcanic calderas produce, depending on their origin, gravity lows (explosive calderas) or highs (collapse calderas).

A characteristic feature of the gravity field in Kamchatka, as compared to other VA systems is the presence of two additional, although less intense, zones of positive gravity anomalies in the area between the Malka-Petropavlovsk zone of transverse faults and the Kamchatka-Aleutian junction. These additional zones are roughly parallel to the principal zone of positive gravity anomalies confined to the eastern peninsulas (Plate 2). One of them, located in the Central Kamchatka Depression, has been delineated rather reliably, while the positive anomaly zone in western Kamchatka is less distinct. The positive anomaly zone in the Central Kamchatka Depression occupies the same position relative to the volcanic belt of the Sredinny Range as does the zone of the eastern peninsulas relative to the volcanic belt of eastern Kamchatka. It coincides nearly completely with the buried part of Khavyvenskaya Rise. The maximum gravity values within this uplift occur on the Khavyvenskaya Rise, which is composed of crystalline schists, serpentinized ultrabasic rock, Late CretaceousPaleocene pillow basalt, and tuff, and intruded by a gabbro body with a density of $3.05 \mathrm{~g} / \mathrm{cm}^{3}$. Elsewhere, the anomalous zone of the Khavyvenka highland is covered by a mantle of Cenozoic volcanoclastic rocks, which lowers the value of the positive gravity anomaly. However, the high gravity effect cannot be explained only by the presence of the high-density rocks [Aprelkov et al., 1985]. In our opinion, the buried Khavyvenskaya Rise was the frontal (tectonic) arc of the subduction zone beneath the Sredinny Range. In this case, the positive gravity anomaly is partly a residual anomaly produced by disturbance of isostasy during subduction. We note too that ophiolite complexes are often distributed in frontal arcs.

The presence of a buried paleotrench, indicated by a negative free-air gravity anomaly along the continental rise east of Karaginsky Is. (Watts et al., 1975), suggests the separate nature of the subduction zone under the Sredinny Range. The Tyushevskiy trough and the Grechishkin overthrust zone in the Kamchatka correspond to this subduction zone, the latter to the western slope of the paleotrench (Fig. 1).

A model vertical gravity section, showing two subduction zones, is presented in Fig. 3. Our gravity modeling across
Kamchatka (profile A - B in Plate 2) indicated that the shape and intensity of the calculated gravity anomaly is close to the measured one if two higher gravity subducting layers with an effective density of +0.08 to $+0.1 \mathrm{~g} / \mathrm{cm}^{3}$ and two lower density zones $\left(-0.08\right.$ to $\left.-0.1 \mathrm{~g} / \mathrm{cm}^{3}\right)$, corresponding to the inferred sites of magma generation, are used into the model.

A third zone of positive gravity anomalies in western Kamchatka seems to mark a Paleogene arc (Plate 2).

\subsection{Seismological Data}

The spatial distribution of earthquake epicenters recorded during 1962-2005 are shown in Plate 3. A belt of shallowfocus earthquakes (less than $50 \mathrm{~km}$ deep) extends along on the continental slope of the deep-sea trench. It is characteristic that all large earthquakes with magnitude more than 7.5 are located within the tectonic arc, above and within the sharp downward bend of the Pacific plate, where the angle of subduction changes from $10-12^{\circ}$ to about $50^{\circ}$ (Plate $3 \mathrm{~B})$. North of the Kamchatka-Aleutian junction, the seismic belt is offset westward, occupying a position relative to the
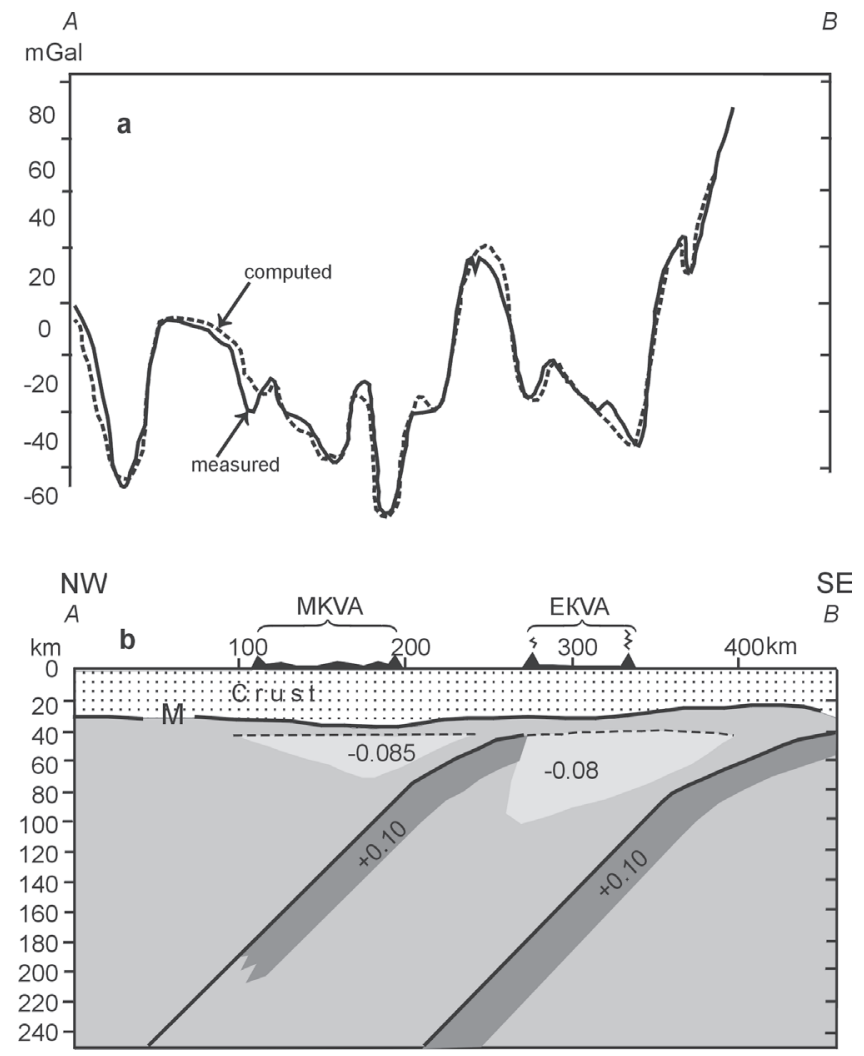

Figure 3. Density model for the mantle at the cross-section along line $A-B$ (Plate 2). Earth's crust density heterogeneities were included into calculations. 
AVDEIKO ET AL. 45

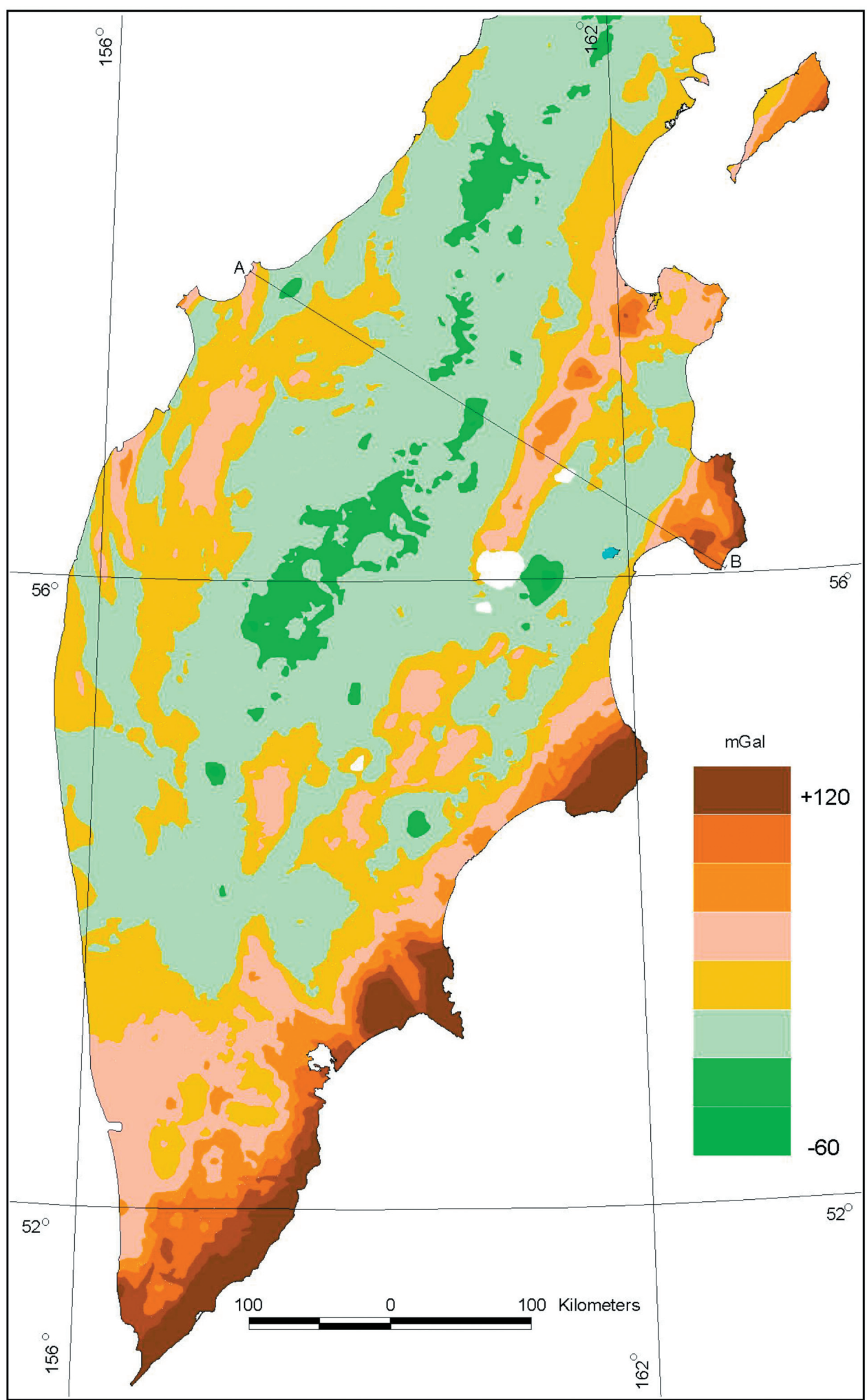

Plate 2. Bouguer gravity anomalies on Kamchatka. A - B - location of model cross-section show in Fig. 3. 

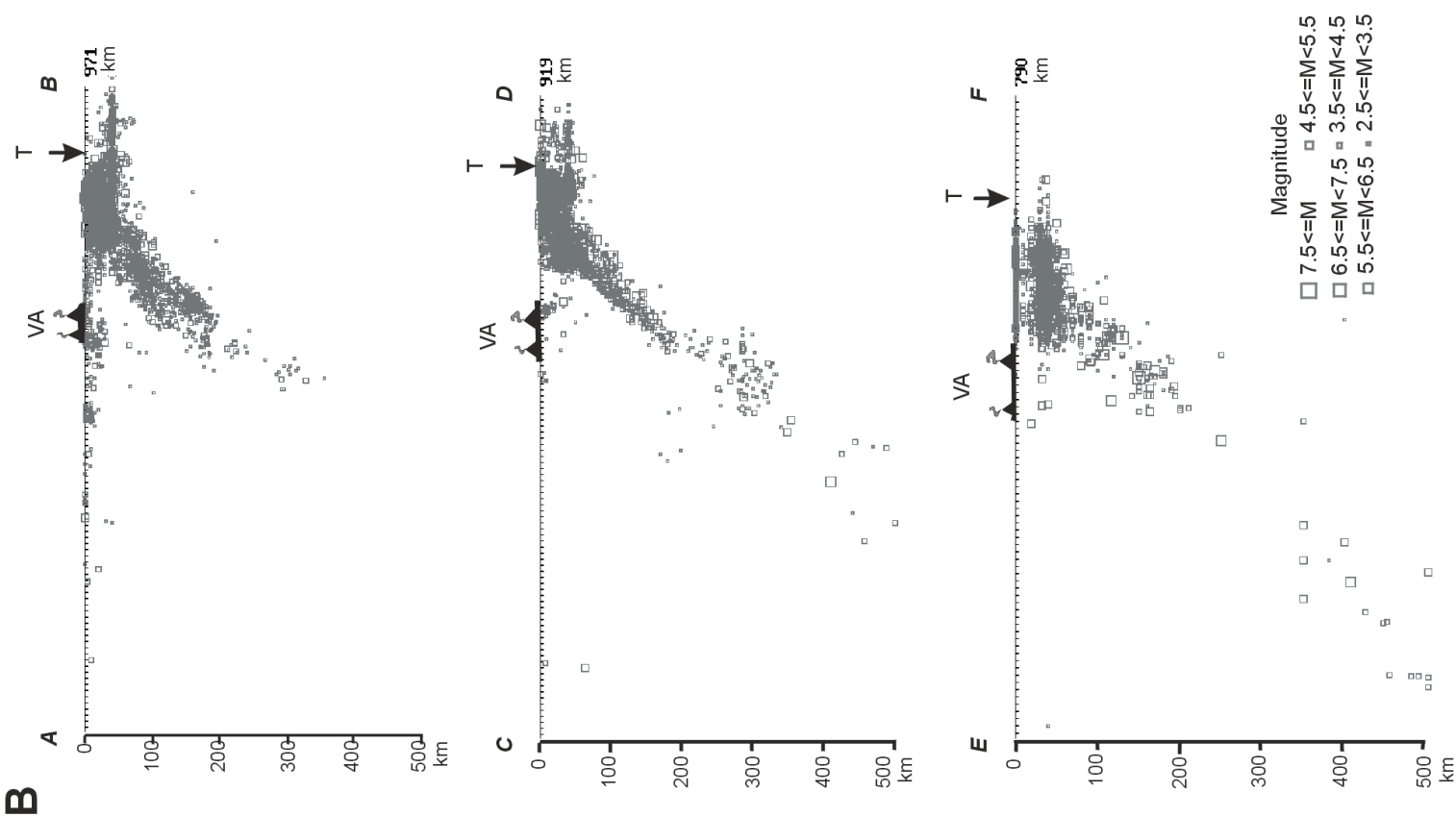

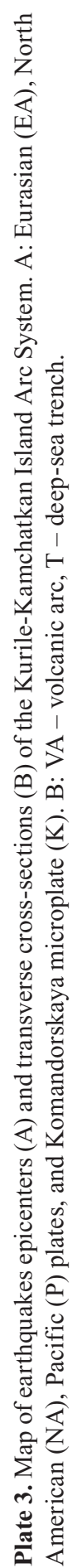

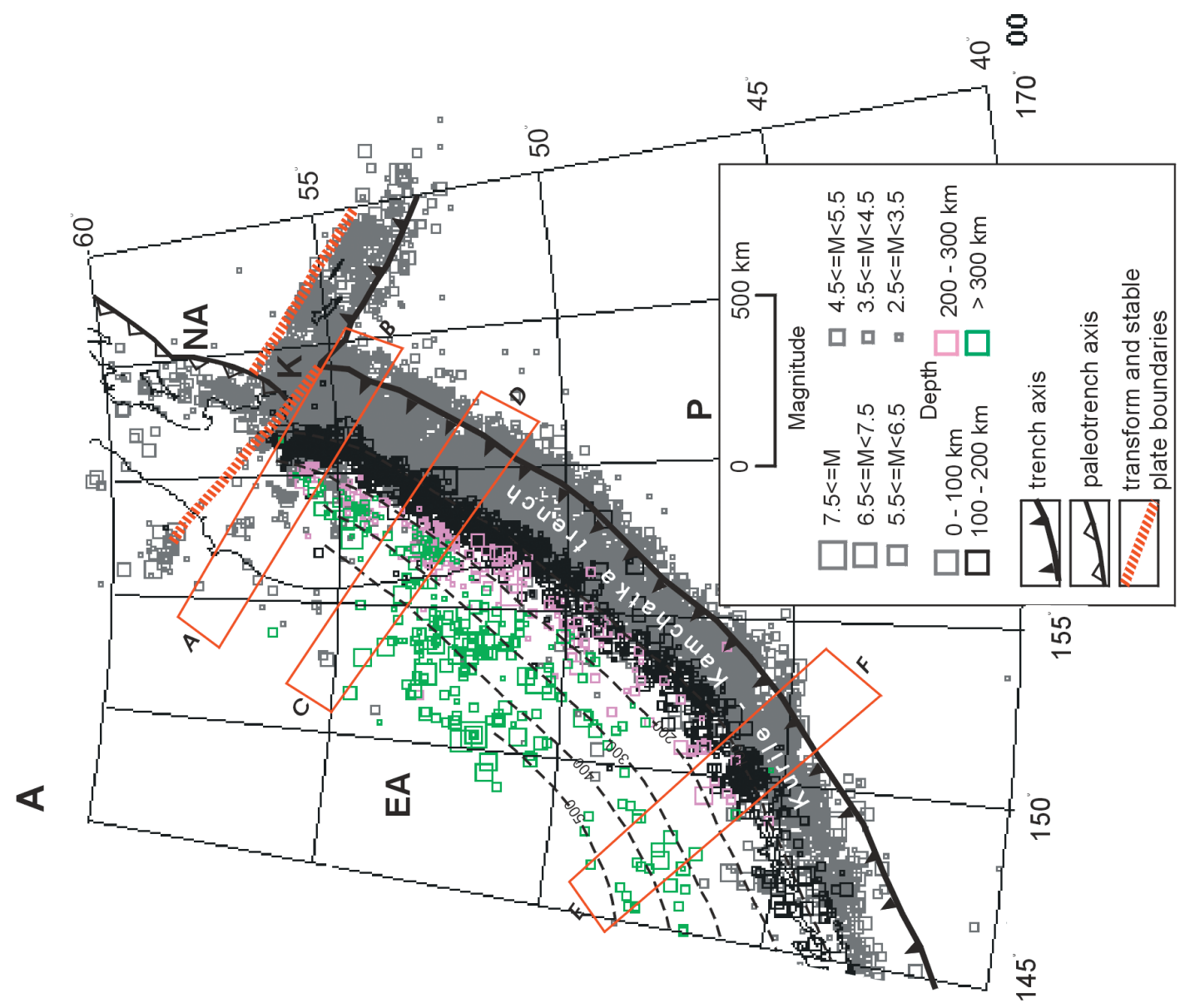


paleotrench as the seismic belt southward the KamchatkaAleutian junction relative to the Kurile-Kamchatka trench. This provides additional evidence in favor of a jump of the subduction zone south of the Kamchatka-Aleutian junction to the present day position. In addition, a great number of shallow-focus earthquakes are recorded in eastern Kamchatka between the Malka-Petropavlovsk zone of transverse faults and a prolongation of the Kamchatka-Aleutian junction on Kamchatka, the segment where we assume the subduction jump took place, whereas few isolated weak earthquakes were recorded in South Kamchatka. This indicates that weak motion still continues along the previous subduction zone, although no longer recorded at greater depths.

\subsection{Geodynamic Characteristics of Volcanic Activity}

Earlier, Avdeiko [1994] discussed the principal geodynamic parameters of volcanism in the Kurile segment of the Kurile-Kamchatka island-arc system based on a subduction model. Benioff seismic zone parameters are known to control aspects of volcanic activity. They exert an effect upon the temperature, pressure, and composition of the melting substratum, the quantity and composition of volatile components participating in the melting process, and the conditions of magma ascent and eruption. Principal parameters include the depth of the subduction zone (to the Benioff zone's upper surface) under the frontal and back-arc volcanoes, the distance between the deep-sea trench axis and the volcanic front, the subduction zone inclination angle, etc.

Recently, in cooperation with V.A. Shirokov, we refined the geometry of the Benioff zone using the data available for the earthquakes in the Kurile-Kamchatka region during the whole period of detailed instrumental observations (1962-2005). The isodepths to the upper surface of the Benioff zone, based on these data, are shown in Fig. 1, and the refined parameters of the structure as it occurs in various portions of the East Kamchatka and Kurile segments of the island-arc system are summarized in Table 1.

The depth of the Benioff focal plane below the volcanic front is nearly constant, at about $110 \pm 5 \mathrm{~km}$, and the maximum depth below the back-arc volcanoes farthest from the volcanic front does not exceed $220 \mathrm{~km}$. Avdeiko [1994] argued that melting conditions in the mantle wedge are confined to this depth interval of the Benioff plane because of release of volatiles, in general water, from the subducted Pacific plate.

The rate of the Pacific Plate subduction varies from 7.5 $\mathrm{cm} /$ year under the Kronotsky Peninsula to $8.3 \mathrm{~cm} /$ year at the latitude of Kunashir Is. [Gorbatov, Kostoglodov, 1997]. This rate and the distance between the deep-sea trench axis and the volcanic-arc front were used to calculate the time
Table 1. Geodynamic parameters of the Quaternary of KurileKamchatka VA system

\begin{tabular}{lccc}
\hline \multicolumn{1}{c}{$\begin{array}{c}\text { Geodynamic } \\
\text { parameter }\end{array}$} & $\begin{array}{c}\text { Easthern } \\
\text { Kamchatka }\end{array}$ & $\begin{array}{c}\text { Avachinsky } \\
\text { Bay }\end{array}$ & $\begin{array}{c}\text { Southern } \\
\text { Kamchatka }\end{array}$ \\
\hline $\mathrm{L}_{\text {min }}, \mathrm{km}$ & $190-200$ & 205 & $200-205$ \\
$\mathrm{~L}_{\mathrm{dir}}, \mathrm{km}$ & $190-200$ & 205 & $200-205$ \\
$\mathrm{~L}_{\mathrm{b}}, \mathrm{km}$ & $130-140$ & 145 & $140-145$ \\
$\mathrm{~V}, \mathrm{~cm} / \mathrm{y}$ & 7.6 & 7.6 & $7.7-7.8$ \\
$\alpha^{\circ}$ & $80-90$ & 90 & $85-90$ \\
$\beta^{\circ}$ & $35-51$ & 51 & $50-51$ \\
$\mathrm{H}_{\mathrm{f}}, \mathrm{km}$ & $105-115$ & 115 & 110 \\
$\mathrm{H}_{\text {max }}, \mathrm{km}$ & 195 & 180 & 205 \\
$\mathrm{t}, \mathrm{m} . \mathrm{y}$. & $2.8-2.9$ & 3 & $2.9-3.0$ \\
$\mathrm{~d}, \mathrm{~km}$ & $50-70$ & 70 & $40-60$ \\
$\mathrm{~T}, \mathrm{~km}$ & $\sim 40$ & $42-47$ & $40-45$ \\
\hline
\end{tabular}

Notes: $\mathrm{L}_{\min }$ and $\mathrm{L}_{\mathrm{dir}}-$ the distance between the trench axes and volcanic front: minimal $\left(\mathrm{L}_{\min }\right)$ and along the direction of the Pacific plate motion $\left(\mathrm{L}_{\mathrm{dir}}\right) . \mathrm{L}_{\mathrm{b}}$ - the distance between the trench axis and the bend in the Pacific plate (a change of subduction angle from $10-12^{\circ}$ to about $50^{\circ}, \mathrm{V}$ - the convergence rate [Gorbatov et al., 1097], $\alpha$ - angle between a direction of the Pacific plate motion and the arc strike, $\beta$ - a subduction angle between $40-500 \mathrm{~km}$, the depth beneath the volcanic front $\left(\mathrm{H}_{\mathrm{f}}\right)$ and the rear volcanoes $\left(\mathrm{H}_{\max }\right)$, $\mathrm{t}$ - the time of the Pacific plate to pass from the trench axis down to $\mathrm{H}_{\mathrm{f}}, \mathrm{d}$-width of the volcanic arc, $\mathrm{T}$-crustal thickness.

for subduction to $110 \mathrm{~km}$ depth where melting of the mantle wedge begins as a result of volatile flux. This time varies from 2.8 m.y. in eastern Kamchatka to 3.2-3.5 m.y. in the southern Kurile Islands.

It should be emphasized that the geodynamic parameters of magma generation and volcanic activity are approximately the same in all VA systems throughout the Circum-Pacific Belt. The principal parameters are as follows: the Benioffzone depth below the volcanic arc varies from $110 \pm 10 \mathrm{~km}$ beneath a volcanic front up to $220 \mathrm{~km}$ beneath the most distant from volcanic front volcanoes; the volcanic-arc width usually is not more then $100 \mathrm{~km}$; and the distance between the deep-sea trench axis, i.e., the subduction starting line and the volcanic front line is not more that $250 \mathrm{~km}$. The position of the volcanic belt in the Kamchatka Sredinny Range does not agree with these parameters. The depth to the presentday Benioff zone in the south of the belt varies from 300 $\mathrm{km}$ below the frontal volcanoes to $450 \mathrm{~km}$ under the reararc volcanoes. As for the area north of Ichinsky volcano, subduction, if present, does not reveal itself in the form of a seismic zone. The width of the Sredinny Range volcanic belt exceeds $100 \mathrm{~km}$, which is comparable with the width of a large volcanic arc. If the volcanic belt of the Sredinny Range is considered as a third volcanic belt connected with present-day subduction zone, then the volcanic arc is as wide as $400 \mathrm{~km}$ within this segment of the Kurile-Kamchatka island-arc system. 


\section{DISCUSSION}

\subsection{Nature of the Volcanic Belt of the Sredinny Range, Kamchatka}

The above geological and geophysical data enable assessment of the conditions of formation of the volcanic belt of the Sredinny Range in Kamchatka. On the one hand, this question is key to reconstructing the history of tectonic development of the Kurile-Kamchatka VA system. On the other hand, it is important for understanding the processes of magma generation related to the subduction.

Connecting the formation of this belt with the present day Kurile-Kamchatka subduction zone is well-described in by Tatsumi et al. [1994; 1995]. In their opinion, the unusual position of this belt and the atypical composition of the volcanic rocks are accounted for by melting of K-amphibole-bearing peridotite at the base of the mantle wedge at anomalously high temperatures. Such high temperature is explained by the unusual tectonic setting of the belt at the edge of the Pacific plate having a transform-type boundary with the North American plate. Calculations made by these authors predict a temperature rise of $200-300^{\circ} \mathrm{C}$ in the boundary of the mantle wedge in comparison with the usual situation.

This explanation could be plausible if the aerial distribution of volcanoes in the Sredinny Range were restricted to the zone of the Kamchatka-Aleutian junction. However, the volcanic belt of the Sredinny Range represented by subduction-related Late Oligocene-Quaternary volcanic formations extends more than $700 \mathrm{~km}$ from latitude $54.8^{\circ} \mathrm{N}$ at Khangar volcano in the south to latitude $60.3^{\circ}$ in the north. It should be emphasized, however, that a zone of anomalously increased temperature does exist, and, in our view, causes formation of high-magnesian basalts and lavas of the intraplate geochemical type along with the typical VA lavas [Volynets, 1994; Volynets et al., 1999; Portnyagin et al., 2005; Avdeiko and Savelyev, 2005].

Seliverstov [1998] believes also that the Sredinny Range volcanic belt formation is connected with the modern KurileKamchatka subduction zone. In his opinion, inclination of the subduction zone in Miocene was more gentle due to subduction of hotter lithosphere. In Pliocene time, the angle of the subducted plate increased and VA belt shifted from the Sredinny Range to the present-day position. This view is unlikely to be the true for the following reasons:

1. It is not clear why subducting Pacific lithosphere should have been hotter in the Miocene. A single cause may be intraplate volcanism, but the age of the nearest volcanoes of the Obruchev rise (Detroit and Meiji Seamounts) is more than 85 m.y. [Regelous et al., 2003].

2. The dip angle of subduction of the young Nasca plate exceeds $23^{\circ}$, whereas the subduction angle zone at the distance of
$320-350 \mathrm{~km}$ between the Kurile-Kamchatka trench axis and the Sredinny Range volcanic belt must be less than $20^{\circ}$.

3. According to Seliverstov [1998], a change of the subduction angle is a continuous process resulting from an increase in the sinking rate due to subduction of a heavier lithosphere. Therefore, the question arises as to why the volcanic zone was offset east ward over a distance of 150 $\mathrm{km}$ (distance between paleovolcanic front of the Sredinny Range and volcanic front of eastern Kamchatka), during a continuous process without leaving any trace in the form of volcanoes.

The data discussed in the previous sections suggest that the volcanic belt of the Sredinny Range was an independent volcanic arc, which was formed above its subduction zone, which jumped to its present-day position in the end of Miocene, as incoming positive-buoyancy lithospheric blocks locked subduction. According to Trubitsyn et al. [1998], these blocks are represented now by the eastern Kamchatka peninsulas. The location of the volcanic arcs and the axes of the deep-sea trenches that mark the subduction zones, are shown in Fig. 1. The principal lines of evidence for this interpretation are summarized below.

1. Spatial distribution and tectonic setting of the volcanic belts and the absence of Miocene island-arc volcanic rocks in eastern Kamchatka, except Late Miocene intraplate lavas (Fig. 1), indicate that the volcanic belts of the Sredinny Range and eastern Kamchatka (along with the belts of the Central Kamchatka Depression) are independent volcanic arcs. Moreover, frontal and rear-arc volcanic zones separated by a zone of weaker volcanic activity have been recognized within the Sredinny Range volcanic arc, as well as in Southern Kamchatka and in the Kurile Islands.

2. The transverse petrochemical zoning of the Sredinny Range volcanic belt is similar to that of other volcanic arcs, though with higher contents of alkali and incompatible trace elements.

3. Gravity data indicate the doubling, and possibly trebling, of crustal thickness of the Sredinny frontal (tectonic) arc (delineated by a belt of positive anomalies)-volcanic arc systems (Plate 2 and Fig. 3).

4. The seismological data (Plate 3) suggest that some residual movements still occur in the subduction zone of the Sredinny Range. It is also possible that these movements continue in the segment between the Malka-Petropavlovsk and Kamchatka-Aleutian junction of transverse faults. These are transform faults that limit the region (segment) of the subduction zone jump (Fig. 1).

5. A paleotrench corresponding to the Sredinny Range subduction zone has been outlined by gravity and seismic reflection and refraction data east of Karaginsky Island. 
The idea of the jump of tectonic zones in Kamchatka, which are regarded as the paleoanalogues of modern VAtrench systems, was put forward by one of the present writers independent of the subduction model [Avdeiko, 1971]. Later, Legler [1977] elaborated the concept as a subduction-zone offset. However, the mechanism of subduction north of the Kamchatka Peninsula, i.e., to the north of the junction with the Aleutian arc, remained unclear. Based on computer modeling, Trubitsyn et al. (1998) showed that subduction and, consequently, volcanism in the northern segment of the Sredinny Range arc had been caused by mantle convection under the Komandorskaya Basin induced by the Pacific Plate motion. A system of back-arc spreading rifts, which corresponds to this interpretation, had previously been discovered within the Komandorskaya Basin [Baranov et al., 1991].

\subsection{Tectonic History}

The data presented above allow us to interpret Cenozoic tectonic history of the Kurile-Kamchatka region as the development of VA subduction systems of different ages, which were offset discretely and consecutively grew younger toward the Pacific Ocean (Fig. 1 and 4). Obviously, a system of volcanic complexes existed in western Kamchatka in the Paleogene (Fig. 1), of which only isolated outcrops of volcanic sheets and subvolcanic bodies remain [Bogdanov, Khain, 2000]. A belt of positive gravity anomalies seems to mark a frontal (tectonic) arc (Plate 2). The intensity of the anomalies has been reduced by partial recovery of isostatic equilibrium.

Beginning from the end of the Oligocene (Fig 4, cross-section 1), a system of two arcs existed within Kamchatka and the Kurile Islands, i.e., the Mid Kamchatka and the South Kamchatka-Kurile arcs. The formation of this system south of the Kamchatka-Aleutian junction was caused by the subduction of the Pacific Plate, while to the north, it was caused by subduction of a young small plate of the Komandorskaya basin. These arcs are marked in the present-day structure by their own volcanic-rock associations (Fig. 1). A frontal (tectonic) arc of this subduction system shown (Fig. 4) now is buried beneath sediments of the Central Kamchatka Depression excluding Havyvenskaya Rise. A positive gravity anomaly marks its position. A paleotrench of this system shown on Fig. 1 is reconstructed as a prolongation of buried trench of Komandorskaya basin and on the basis of geodynamic parameters of modern Kurile-Kamchatka subduction system (Table 1). A portion of sediments deposited on this trench continental slope was eroded, a portion is shown on the generalized map as Oligocene-Miocene deposits of Eastern Kamchatka, and a portion was covered by volcanic rocks of East Kamchatka VA. Fragments of these deposits were carried upward as xenolites during Large Tolbachik eruption (Fedotov et al., 1984).
In the end of the Miocene, the subduction zone of the Pacific Plate within the segment from the Shipunsky Peninsula to the Kamchatka-Aleutian junction was blocked by the accretion of the eastern Kamchatka peninsulas and, probably, some other structural elements of eastern Kamchatka. As a result, the subduction zone jumped to its present-day position, and the Kurile-Kamchatka island-arc system acquired its present-day shape (Fig. 1). Geodynamic conditions changed. The area of the Miocene trench, where a negative isostatic anomaly was present, began to elevate as isostatic equilibrium was restored. In contrast, the Miocene frontal arc began to subside, forming the Central Kamchatka Depression. Opposite movements led to formation of a fault zone probably with a thrust component due to compression.

We postulate the forming of a plate gap, and consequently opening of mantle windows, after cessation of subduction (Fig. 4, cross-section 2). This breakage is possible as a result of increase of plate sinking after eclogitization. P-wave seismic tomography appears to show a gap in the slab at a depth of 450-600 km [Gorbatov et al., 2000, Fig. 7, cross-section E-E']. This cross-section is located in the central part of Kamchatka, where the jump of subduction zone took place. We suggest that the high velocity body in this cross-section at the depth about $600-1000 \mathrm{~km}$ was torn away from the Pacific plate after subduction stopped beneath the Sredinny Range. There is no such gap in the cross-section D-D' located beneath southern Kamchatka, where no jump of the subduction zone occurred, i.e. in the segment of the steady-state regime of subduction.

An inter-arc trough formed between frontal and volcanic arcs. It is suture zone, were sediments of the lower slope of the Miocene trench were accumulated. They are shown as Oligocene-Miocene inter-arc deposits including terrigenous mélange on Plate 1. Later some of them were covered Quaternary unconsolidated deposits.

\subsection{Volcanic-Tectonic Zonation}

Our interpretation of volcanic-tectonic zonation is based on the principle of classifying volcanic arcs by the ages of the subduction zones and the episodes of volcanic activity. The present-day Kurile-Kamchatka VA system can be subdivided into segments based upon variations in geodynamic parameters of the subduction zone, which are also reflected in the spatial distribution and tectonic setting of the volcanoes and by the composition of the volcanic rocks. Since we did not find any effects of the age or the composition of the basement rocks upon the composition of the volcanics in the Kurile-Kamchatka VA system, we do not use this parameter in defining the volcanic-tectonic zonation. 


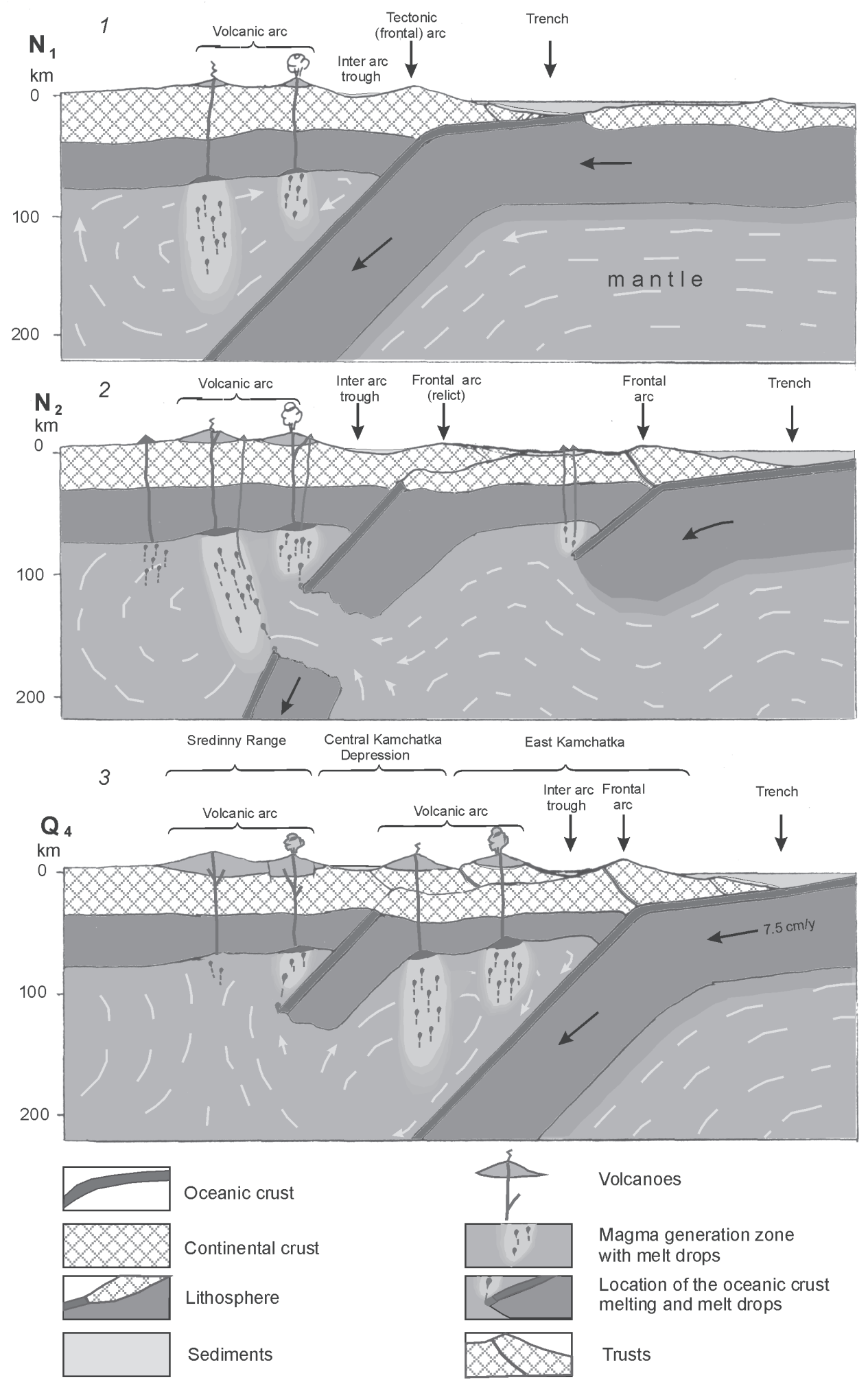

Figure 4. Model cross-sections of evolution of the Kurile-Kamchatka island arc system (after Avdeiko et al., 2001 with correction). See Fig. 1 for location of cross-sections. 
Three volcanic arc-deep-sea trench systems of different ages that become successively younger toward the Pacific Ocean have been recognized in the region: the West Kamchatka (Eocene), Mid Kamchatka-Kurile (Late Oligocene-Miocene), and Recent Kurile-Kamchatka systems. These volcanic arcs form the rigid framework of the present-day tectonic structure of the Kurile-Kamchatka island-arc system. Sedimentary troughs separating these arcs are either forearc or back-arc basins.

We recognize the following segments within the KurileKamchatka VA system based on the tectonic evolution and geodynamics of the present-day volcanic activities above the zone of the Pacific Plate subduction under the Eurasian Plate.

The East Kamchatka segment represents the initial stage (7-10 Ma) of an orthogonal subduction process. The subsidence of the Pacific Plate margin to a depth of approximately $110 \mathrm{~km}$, where the separation of initial magmatic melts becomes possible and over which the volcanic front is located, lasted 2.8-2.9 m.y. This implies that subduction must have commenced before the extrusion of the associated oldest volcanic rocks, i.e., in the latest Miocene. This segment consists of various components, with an area where the lithospheric plate carrying normal oceanic crust is underthrust at an angle of $50^{\circ}$, and an area where the oceanic crust, thickened owing to the presence of the Obruchev Rise, is subducted at an angle of about $30^{\circ}-35^{\circ}$. This segment also includes the Kamchatka-Aleutian junction.

The Petropavlovsk segment (the Malka-Petropavlovsk transverse-fault zone) is a zone of discordant superposition of the present-day Kurile-Kamchatka arc of NE trend upon the Malka-Petropavlovsk segment of the Middle KamchatkaKurile VA system, having a NW trend there. In the south Kamchatka segment, as well as in the three Kurile segments, subduction began at the end of the Oligocene. A virtually stationary subduction zone persisted there for about 25 -m.y. We postulate that westward shift of the volcanic front was caused by the cooling effect of the subducted Pacific Plate and a consequent shift of the magma-generation zone in the mantle wedge in the same direction as slab motion. We have subdivided the Kurile segment of the Kurile-Kamchatka arc into the North, Middle and South Kurile segments, with different geodynamic characteristics of the subduction zone and subduction-related volcanism (Table 1). Both the frontal and back volcanic zones, separated by a zone of weaker volcanic activity, are distinctly displayed in each segment of the volcanic arcs.

\subsection{Geodynamics of the Kamchatka-Aleutian Junction}

Geodynamical conditions of this area have evolved over the last $40 \mathrm{Myr}$ due to interaction of the Pacific, North
American, Eurasian and Kula plates and Komandorskaya microplate. The junction assumed its present shape during the last 7-10 Myr, after blockage of the Pacific plate subduction under the Sredinny Range of Kamchatka and its jump to the present-day position (Fig. 1 and 4). Both the jump and the arrow-like shape of the Kamchatka-Aleutian junction are in large measure caused by the Hawaiian-Emperor volcanic chain. The proposed geodynamic model of the KamchatkaAleutian junction (Fig. 5) assumes gradual westward transfer of motion from oblique subduction of the Aleutian arc to the transform fault near Kamchatka. The braking effect of the motionless North American plate upon the moving and subducting Pacific plate results in a tension and sometimes rupture of the latter (slab-windows) and intrusion of hotter below-slab material into the mantle wedge. One such slabwindow probably occurs under the Kluchevskaya group of volcanoes and is the reason for their high productivity and the magnesian composition of their rocks. Additionally, separation of the Pacific slab-edge blocks, their sinking into the mantle, and subsequent heating can lead to generation of small mantle plumes (Fig. 5). One such plume is confirmed by seismic tomography data [Gorbatov et al., 2000; Levin et al., 2002] and by the presence of the OIB-like rocks [Portnyagin et al., 2005]. The large variety of volcanic rocks from usual VA-type up to the intraplate type is caused by varying contributions of mantle materials from the hot below-slab zone, mantle wedge and also by the fluid and/or melt separated from the slab. The role of fluids in magma generation decreases, while the role of slab melt increases in the direction from the Kluchevskaya group of volcanoes to the northern volcanoes Hailula and Nachikinsky [Portnyagin et al., 2005a].

The braking effect also was a cause of forming Komandorskaya microplate, which separated from North American plate. Northwestward motion of this microplate at $3.7 \mathrm{~cm} / \mathrm{y}$ was determined from GPS data (Fig. 1 and 5) after the Kronotsky 1997 earthquake (Levin et al., 2002).

\subsection{Geodynamic Conditions of Magma Generation}

Magma generation is one of the most important problems in volcanology and petrology. The Kurile VA system is an appropriate object to solve this problem, because geodynamics conditions varied in space and time during its evolution. Geodynamics controlled the magma generation and geochemical characteristics of volcanic rocks. Magma generation beneath the Kurile Island Arc [Avdeiko, 1999] corresponding to a steady-state regime of subduction takes place in the mantle wedge under the influence of fluids derived from the subducted slab. Frontal and rear volcanic zones are formed above two zones of magma generation, 


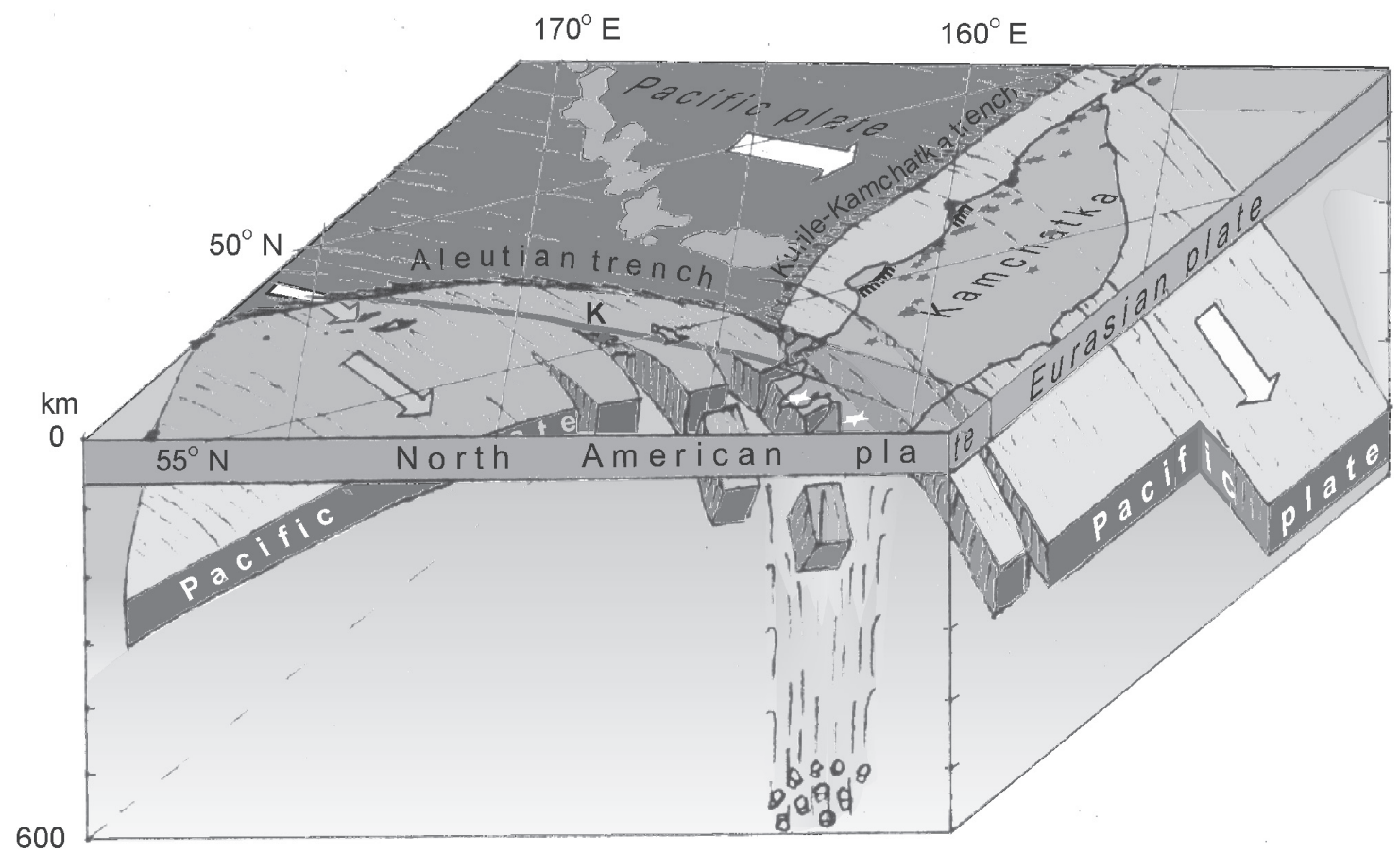

Figure 5. 3D-model of the geodynamics of the Kamchatka-Aleutian junction as a view from North West. Black starsactive volcanoes, white stars - Nachikinsky (N) and Khailula (K) extinct volcanoes located off the edge of Pacific plate, K - Komandorskaya microplate, which separated from North American plate. Some lithosphere blocks are torn off the Pacific plate edge as a result of interaction (breaking) with North American plate. These blocks, having a negative buoyancy, sink into a mantle, are heated, and can form a small mantle plume.

controlled by two levels of dehydration of water-bearing minerals in the slab. Varying composition of the fluids result from differences in compositions of the dehydrating of waterbearing minerals. Amphiboles (including tremolite) and chlorites from the layers 1 and 2 of the oceanic crust are dehydrated beneath the frontal arc zone, and serpentine and talc from the 3B layer are dehydrated beneath the rear one. Additionally, aqueous fluid separating beneath the frontal zone passes upward to the zone of magma generation only through the wedge base, whereas fluid separating beneath the rear zone rises successively through layers $3 \mathrm{~A}, 2$ and 1 of oceanic crust as well as a longer way through the mantle wedge to the zone of magma generation. The fluid separating from the slab beneath the rear zone has a higher temperature in comparison with the frontal one. Typical VA magmas are generated beneath the frontal and the rear zones under the steady-state regime of subduction.

What are conditions of the occurrence in Kamchatka of volcanic rocks of an intraplate geochemical type along with the considerably more abundant typical VA rocks? In contrast to the typical VA lavas characterized by the low concentrations of $\mathrm{Ta}, \mathrm{Nb}$, and $\mathrm{Ti}$, the intraplate lavas show higher abundances of these elements (Fig. 2) [Volynets, 1994; Avdeiko and Savelyev, 2005]. The low $\mathrm{Ta}, \mathrm{Nb}$, and Ti concentrations in typical VA magmas are due to the fact that these elements, that reside principally in rutile, are poorly soluble in fluids [Tatsumi et al., 1986]. However, partial melting of oceanic-crust basalt under water-saturated conditions is possible at temperatures exceeding $750^{\circ} \mathrm{C}$ [Peacock et al., 1994], and these melts contain, according to experimental data, higher $\mathrm{Ti}, \mathrm{Nb}$, and $\mathrm{Ta}$ concentrations especially at depths below $150 \mathrm{~km}$ where rutile is unstable [Ringwood, 1990]. Thus, appearance of intraplatetype lavas may be due to partial melting of oceanic crust because of higher temperatures that prevail within the slab in the steady-state regime of subduction. Where can there be such higher slab temperatures? It should be noted, first of all, that intraplate-type volcanic rocks are present only within the segment between the zone of the Malka-Petropavlovsk transverse faults and the Kamchatka-Aleutian junction (Fig. 1), i.e. in the segment of the subduction zone that jumped in the Late Miocene. Melting of the frontal edge of the subducting plate was possible at the contact with the hot mantle during the initial stage of the subduction, as, for instance, in eastern Kamchatka during the end of Miocene-beginning the Pliocene (Fig. 4).

Similar conditions for partial melting of the subducting plate seem to have existed at the Kamchatka-Aleutian junction, at the northern edge of the Pacific plate, where the 
upper mantle has high temperatures [Tatsumi et al., 1994]. Such conditions can occur beneath fracture zones forming slab windows at some distance south the plate edge, where intrusion of hot asthenospheric material through the slab window takes place (Fig. 5).

The formation of the Sredinny Range intraplate-type rocks coincided in time with the subduction zone jump and also connected with a mantle window as we discussed in section 3.2 (Fig. 4). Oceanic crust can melt in a contact with hot under-slab mantle material intruded into slab window.

The termination of subduction under the Sredinny Range might have caused the detachment of the heavier lower portion of the oceanic crust (with underlying lithosphere), its sinking below the eclogitization zone depth (deeper than 150 $\mathrm{km}$ ), and the intrusion of a hot mantle material from under the slab into the resulting gap (Fig. 4). This might have been accompanied by the melting of layers 1 and 2 of oceanic crust upon the contact with this material.

Thus, we explain the occurrence of intraplate-type rocks in all three instances by the melting the upper portion of the subducted plate (oceanic crust) at its contact with the hotter mantle. We must qualify that this hypothesis is advanced here in the most general form and requires a more thorough evaluation by computing temperature distributions in anomalous areas, seismic tomography, and more detailed petrochemical and geochemical data. Studies aimed at testing this hypothesis have already been initiated within the framework of the Russian-German KALMAR Project. Another scenario for such lavas is low-percentage melting of mantle with little slab input (e.g. Abratis and Wörner, 2001). Such scenario is possible for the Sredinny Range and west Kamchatka. A hot mantle material rises in plate gap (Fig. 4. cross-section 2) and higher may give small portion melt as a result of decompression.

\section{CONCLUSIONS}

We have distinguished the following segments in the present-day Kurile-Kamchatka island-arc system based on the distinctive features of their geological structure and geodynamic parameters: the East Kamchatka, Petropavlovsk, South Kamchatka, North Kurile, Central Kurile, and South Kurile segments. The East Kamchatka segment exemplifies an early subduction stage, the Petropavlovsk segment is complicated by a transverse fracture zone, while the South Kamchatka and Kurile segments have been steady-state for a long time. In contrast, the Mid Kamchatka volcanic arc represented by the Sredinny Range is in a waning stage, because subduction jumped eastward when formation of east Kamchatka capes blocked subduction. Mid Kamchatka arc volcanism extended north of the Kamchatka-Aleutian junc- tion because of subduction of western Komandorsky Basin crust, driven by back-arc spreading. Intraplate-type magmas enriched in $\mathrm{Ta}, \mathrm{Nb}$, and $\mathrm{Ti}$ are generated by the systems at the onset and cessation of subduction and over slab windows, apparently by melting of slab oceanic basalt.

Other scenarios for appearance of intraplate-type lavas are possible, but all must be consistent with their restriction to the area of the Kurile-Kamchatka system where a jump in subduction took place.

Acknowledgements. We thank Oxana Evdokimova and Dmitry Isaev for help in the preparation of this paper. We are very grateful to John Eichelberger and Pavel Izbekov for discussion and correction of the manuscript. We also thank two anonymous reviewers for valuable comments that obliged us to make some improvements.

\section{REFERENCES}

Abratis, M., and Wörner, G., Ridge collision, slab-window formation, and the flux of Pacific asthenosphere into the Caribbean realm. Geology, 29, 127-130, 2001.

Aprelkov, S. E., Smirnov, L. M., and Ol'shanskaya, O. N., The Origin of Gravity Anomaly in Central Kamchatka Depression, in: Modeling of Deep Geological Structures from Gravity and Magnetic Data, Vladivostok: PED RAS, 68-71, (in Russian), 1985.

Avdeiko G. P., Evolution of geosynclines on Kamchatka. Pacific Geology, 3, 1-13, 1971.

Avdeiko G. P., On possible prolongation of the Hawaiian-Emperor chain in Kamchatka, in: Jackson, E.D., and Koisumi,I et al. Initial Reports of Deep Sea Drilling Project. Washington D.C., 55, 851-854, 1980.

Avdeiko, G. P., Geodynamics of Volcanic Occurrences in the Kurile Island Arc and Evaluation of Magma Generation Models. Geotectonika, 2, 19-32, (in Russian), 1994.

Avdeiko, G. P., Antonov, A. Ju., Volynets, O. N. et al., Submarine volcanism and zonality of the Kurile Island Arc. Moskow, Nauka, 528 p., (in Russian), 1992.

Avdeiko, G. P., Pilipenko, G. P., Palueva, A. A., Napylova, O. A., Geotectonic settings of modern hydrothermal manifestations in Kamchatka. Volcanology \& Seismology, 20, 695-711, 1999.

Avdeiko, G. P., Popruzhenko, S.V., Palueva, A.A., Modern structure of the Kurile-Kamchatka region and magma-forming conditions, in: Geodynamics and volcanism of the Kurile-Kamchatka Island-Arc system, Petropavlovsk-Kamchatsky, 9-33, (in Russian), 2001

Avdeiko, G. P., Popruzhenko, S. V., and Palueva, A. A., The Tectonic Evolution and Volcano-Tectonic Zonation of the Kuril-Kamchatka Island-Arc System. Geotectonics, 36 (4), 312-327, 2002.

Avdeiko, G. P., Volynets, O. N., Antonov, A. Yu., Tsvetkov, A. A., Kurile island-arc volcanism:structural and petrological aspects. Tectonophysics, 199, 271-287, 1991.

Avdeiko, G. P., and Savelyev, D. P., Two types of "intra-plate" lavas on Kamchatka, in Problems of sources of deep magmatism and plumes, Proceeding of International Workshop, PetropavlovskKamchatsky - Irkutsk, 229-246, 2005. 
Baluev, E. Yu., Perepelov, A. B., Anan'ev, V. V., and Taktaev, V. I., Forearc high-potassium andesites (Kamchatka). Dokl. Akad. Nauk SSSR, 279 (4), 977-981, (in Russian), 1979.

Baranov, B. V., Seliverstov, N. I., Murav'ev, A. V., and Muzurov, E. L., The Komandorsky Basin as a product of spreading behind a transform plate boundary. Tectonophysics, 199, 237-270, 1991.

Bogdanov, N. A., Khain, V. E., (Eds), Tectonic map of the Sea of Okhotsk region, scale 1:2500000 (2 sheets) with explanatory notes. Moskow, Institute of the Lithosphere of Marginal Seas, 2000.

Churikova, T., Dorendorf, F., and Wörner, G., Sources and fluids in the mantle wedge below Kamchatka: Evidence from acrossarc geochemical variation. Journal of Petrology, 42, 1567-1593, 2001.

Fedorchuk, A. V., Oceanic and back-arc basin remnants within accretionary complexes: geological and geochemical evidence from Eastern Kamchatka. Ofioliti, 17 (2), 219-242, 1992.

Fedotov S. A. et al. (Eds), The 1975-1976 Large Tolbachik Fissure Eruption in Kamchatka, Moscow, Nauka, (in Russian), 1984.

Filatova, N. I., Circum-oceanic volcanic belts. Nedra, Moscov, (in Russian), 1988.

Gorbatov, A., Kostoglodov, V., Maximum depth of seismicity and thermal parameter of the subducting slab: general empirical relation and its application. Tectonophysics, 277, 165-187, 1997.

Gorbatov, A., Vidiyantoro, S., Fukao, Y. \& Gordeev, E., Signature of remnant slabs in the North Pacific from P-wave tomography. Gephys. J. Int., 142, 27-36, 2000.

Harabaglia, P., Doglioni, C., 1998. Topography and gravity across subduction zones. Geophys. Res. Lett., 25 (5), 703-706.

Honda, S., Uyeda, S., Thermal process in subduction zones - a review and preliminary approach on the origin of arc volcanism. Arc volcanism: physics and tectonics, Tokio: Errapub, 117 - 140, 1983.

Khubunaya, S. A., The High-Al Plagioclase Tholeite Association of Island Arcs, Moscow: Nauka, 1987.

Konstantinovskaia, E. A., Geodynamics of an Early Eocene arccontinent collision reconstructed from the Kamchatka Orogenic Belt, NE Russia. Tectonophysics, 325, 87-105, 2000.

Konstantinovskaia, E. A., Arc-continent collision and subduction reversal in the Cenozoic evolution of the Northwest Pacific: an example from Kamchatka (NE Russia). Tectonophysics, 333, 75-94, 2001.

Kozhemyaka, N. N., Active volcanoes of Kamchatka: spatial and temporal dynamics of eruptive intensity and productivity. Volcanology \& Seismology, 22 (1) 25-34, 2000.

Legler, V. A., Development of Kamchatka in Cenozoic according the theory of lithosphere plate tectonics (energy sources of tectonic development and plate dynamics), in: Tectonics of lithosphere plate, Moskow, Institute of Oceanology, 137-169, 1977, (in Russian).

Levashova, N. M., Shapiro, M. N., Ben'yamovskii, V. N., and Bazhenov, M. L., Kinematics of the Kronotskii Island Arc (Kamchatka) from Paleomagnetic and Geological Data. Geotectonics, 34 (2), 141-159, 2000.
Levin, V. E., Gordeev, E. I., Bakhtiarov, V. F., Kasahara, M., Preliminary Results From GPS Monitoring in Kamchatka and the Komandorskie Island. Volcanology and Seismology, 1, 3-11, 2002, (in Russian).

Levin, V., Shapiro, N., Park, J., and Ritzwoller, M., Seismic evidence for catastrophic slab loss beneath Kamchatka. Nature, 418, 763-767, 2002.

Litvinov, A. F., Patoka, M. G. \& Markovsky, B. A., (Eds), Map ot the mineral resources of Kamchatka region, scale 1: 500000 , St.-Peterburg, Kamchatprirodresource, 19 sheets, 1999.

Miyashiro, A., Volcanic rock series in island arcs and active continental margins. Amer. J.Sci., 274 (4), 321-355, 1974.

Melekestsev, I. V., Braitseva, O. A., Ponomareva, V. V., A new approach to definition of the term "active volcano", in: Geodynamics and volcanism of the Kurile-Kamchatka Island-Arc system, Petropavlovsk-Kamchatsky, 191-203 (in Russian), 2001.

Ogorodov, N. V., Kozhemyaka, N. N., Vazheevskaya, A. A., and Ogorodova, A. S., Volcanoes and Quaternary volcanism of Sredinny Ridge of Kamchatka: Moskow, Nauka, 1972, (in Russian).

Osipenko, A. B., Lateral variations in the chemistry of rock-forming minerals in the backarc zone of the Kurile Island: amphiboles. Volcanology \& Seismology, 22 (1), 143-160, 2000.

Osipenko, A. B., Konilov, A. N., Savelyev, D. P., Krylov, K. A., and Anikin, L. P. Geology and Petrology of Amphibolites from Cape Kamchatskii, Eastern Kamchatka. Petrology, 13 (4), 381-404, 2005

Piscunov, B. N., Geological and petrological specificity of island arc volcanism, Moscow, Nauka, (in Russian), 1987.

Portnyagin, M., Hoernle, K., Avdeiko, G., Hauff, F., Werner, R., Binderman, I., Uspensky, V., Garbe-Schönberg, D., Transition from arc to oceanic magmatism at the Kamchatka-Aleutian junction. Geology, 33 (1), 25-28, 2005a.

Portnyagin, M. V., Savelyev, D. P., and Hoernle, K. Plume-Related Association of Cretaceous Oceanic Basalts of Eastern Kamchatka: Compositions of Spinel and Parental Magmas. Petrology, 13 (6), 571-588, 2005b.

Peacock, S. M., Rushmer, T., Thompson, A. B., Partial melting of subducting oceanic crust. Earth and Planetary Science Letters, 121, 227-244, 1994.

Popruzhenko, S. V., Aprelkov, A. E., \& Olshanskaya, O. N., The East Kamchatkan volcanic belt as reflected by geophysical data. Volcanology \& seismology, 9 (2), 200-216, 1990.

Regelous, M., Hofmann, A.W., Abouchami, W., and Galer, S. J. G., Geochemistry of Lavas from the Emperor Seamounts, and the Geochemical Evolution of Hawaiian Magmatism from 85 to 42 Ma. Journal of Petrology, 44 (1), 113-140, 2003.

Rikhter, A. V., Structure of metamorphic complexes of the Ganalsky Range (Kamchatka). Geotectonics, 25 (1), 75-83, 1991.

Rikhter, A. V., Structure of metamorphic complexes of the Central Kamchatka massif. Geotectonics, 29 (1), 65-72, 1995.

Ringwood, A. E., Slab-mantle interactions. 3.Petrogenesis of intraplate magmas and structure of the upper mantle. Chem.Geol., 82, 187-207, 1990. 
Savelyev, D. P., Intraplate alkali basalts in the Cretaceous accretionary complex of the Kamchatkan Peninsula (Eastern Kamchatka). Volcanology \& Seismology, 1, 14-20 (in Russian), 2003.

Sheimovich, V. S., Patoka, M. G., Geology of areas active Cenozoic volcanism. Moscow: GEOS, (in Russian), 2000.

Seliverstov, N. I., Geological structure of Near-Kamchatka bottom and geodynamics of junction zone of Kurile-Kamchatka and Aleutian island ars, Moskow, Nauchnyi Mir, 1998.

Sergeyev, K. F., Krasny, M. L., (Eds), Geology-geophysical atlas of the Kurile-Kamchatka island system, Leningrad, VSEGEI, 36 sheets, 1987.

Sun, S. S. \& McDonough, W. F., Chemical and isotopic sistematics of oceanic basalts; implications for mantle composition and processes. In: Saunders, A. D. \& Norry, M. J. (cds) Magmatism in the Ocean Basins. Geological Society, Landon, Special Publications 42, 313-345, 1989.

Tatsumi, Y., Migration of fluid phases and genesis of basalt magmas in subduction zones. J.Geophys. Res., 94 (B4), 4697-4707, 1989.

Tatsumi, Y., Furukawa, Y. Kogiso, T. et al., A third volcanic chain in Kamchatka: thermal anomaly at transform/convergence plate boundary. Geophys. Res. Lett., 21 (7), 537-540, 1994.

Tatsumi, Y., Hamilton, D.L., Nesbitt, R.W., Chemical characteristics of the fluid phase released from a subducted lithosphere and the origin of arc magmas: evidence from high pressure experiments and natural rocks. J. Volcanol. Geotherm. Res., 29 (1-4), 293 - 309, 1986.

Tatsumi, Y., Kogiso, T., Nohda, S., Formation of a third volcanic chain in Kamchatka: generation of unusual subduction-related magmas. Contrib Mineral. Petrol. 120, 117 - 128, 1995.

Trubitsin, V. P., Shapiro, M. N., and Rykov, V. V., Numerical modeling of the Prepliocene mantle flow in the junction zone of the Kuril-Kamchatka and Aleutian Island Arcs. Physics of the Solid Earth, 4, 10-19 (in Russian), 1998.

Tsukanov, N. V. The Late Mesozoic-Early Cenozoic Tectonic History of the Pacific Coastal Zone of Kamchatka, Moscow: Nauka, 1991.

Vinogradov, V. I., Grigoriev, V. S., Leites, A. M., Age of metamorphism of the rocks from the Sredinny Range of Kamchatka. Izv. Acad. Nauk SSSR. Ser. Geol. 9, 30-38 (in Russian), 1988.
Volynets, O. N., Geochemical types, petrology and genesis of Late Cenozoic volcanic rocks from the Kurile-Kamchatka island-arc system. Intern. Geol. Rev., 36, 373-405, 1994.

Volynets, O. N., Avdeiko, G. P., Tsvetkov, A. A., Antonov, A. Yu., Markov, I. A., Filosofova, T. M., Mineral zoning in the Quaternary lavas of the Kurile Island Arc. Intern. Geol. Rev., 32 (2), 128-142, 1990.

Volynets, O. N., Melekestsev, I. V., Ponomareva, V. V. \& Yogodzinsky, J. M., Kharchinskii and Zarechnyi volcanoes-unique centers of Late Pleistocene magnesian basalts in Kamchatka: structural setting, morphology, globalic structure and age. Volcanology \& Seismology, 20 (4-5), 383-400, 1999a.

Volynets, O. N., Melekestsev, I. V., Ponomareva, V. V. \& Yogodzinsky, J. M., Kharchinskii and Zarechnyi volcanoes-unique centers of Late Pleistocene magnesian basalts in Kamchatka: composition of erupted rocks, Volcanology \& Seismology, 21 (1), 45-66, 1999b.

Volynets, O. N., Puzankov, Ju.M., Anoshin, G. N., Geochemistry of Neogene-Quaternqry volcanic series in kamchatka. In: Geochemical typification of magmatic and metamorphic rocks in Kamchatka. Proceeding of the Institute of Geology and Geophysics, Novosibirsk, 390, 73-114 (in Russian), 1990.

Volynets, O. N., Uspenskiy, V. S., Anoshin, G. N. et al, Geochemistry of Late Cenozoic basalts from East Kamchatka and implications for geodynamic evolution of magma generation. Volcanology \& Seismology, 12 (5), 560-575, 1992.

Watts, A. B., Gravity field of the Northwest Pacific Ocean basin and its margin: Aleutian island-arc trench system: Geological Society of America Map and Chart Series, MC-10, 1975.

Watts, A. B., Kogan, M. G., Bodine, J. H., Gravity field of the Northwest Pacific Ocean basin and its margin: Kuril island arctrench system: Geological Society of America Map and Chart Series, MC-27, 1978.

Yogodzinski, G. M., Lees, J. M., Churikova, T. G., Dorendorf, F., Wörner, G. \& Volynets, O. N., Geochemical evidence for the melting of subducting oceanic lithosphere at plate edges. Nature, 409, 500-504, 2001. 
